\title{
Late Quaternary sediments on the carbonate platform off western India: Analogues of ancient platform carbonates
}

\author{
V Purnachandra RaO* and P Gopinathan \\ Department of Civil Engineering, Vignan's University, Vadlamudi, Guntur 522 213, India. \\ *Corresponding author. e-mail: vprao55@gmail.com
}

MS received 11 June 2018; revised 17 August 2018; accepted 9 September 2018; published online 21 March 2019

The Late Quaternary carbonate sediments and sedimentary rocks from the platform off western India were reviewed for their genesis and relationship with their ancient counter parts. Sub-marine cemented and vadose diagenetic limestones were recovered at different locations on the platform and, neomorphic limestones and caliche pisolites were recovered on the continental shelf south of the platform. Dolomites on the platform were primary and formed by microbial processes under hypersaline, sulphate-reducing conditions during the lowered sea levels. Aragonite ooids were formed from the mineralization of microbial filaments that enveloped their cortex portions. Phosphorites were found in organic-rich, aragonite muds on the continental slope adjacent to the platform and formed from the microbial mineralization of organic matter and replacement of carbonate by apatite during early diagenesis. Microbial processes thus played an important role in the formation of dolomites, ooids and phosphorites reported here and those in ancient deposits. Halimeda bioherms on the platform were grown luxuriantly from the nutrients brought by upwelling currents during the Late Pleistocene-Early Holocene sea level transgression and are similar to the Holocene-Recent deposits in the Indo-Pacific region. Lime muds were bio-detrital and formed primarily from the disintegration of Halimeda bioherms and carbonate skeletal on the platform and then exported to the slope. They resemble fine-grained limestones abundantly reported in ancient platforms. Thus, the different carbonate components on the platform are genetically related to their ancient ones and serve as Late Quaternary analogues for the ancient platform carbonates.

Keywords. Carbonate sediments; dolomites; phosphorites; lime muds; ooids; analogues.

\section{Introduction}

Carbonate platform is a sedimentary body which possess topographic relief and composed of autochthonous calcareous deposits (Wilson 1975). Clear water and favourable climatic and oceanographic conditions are necessary to produce carbonate sediments on the platform. However, the growth potential of the platform is controlled by the initial topography of the platform, sediment production rate, relative sea level and direction and magnitude of winds and currents (Fulthorpe and Schlanger 1989; Eberli et al. 2004). Academic research to study ancient and recent examples of carbonate systems has been increased dramatically in view of the discovery of important oil fields associated with ancient carbonate platforms (Kuznetsov 1997; Kusumastuti et al. 2002; Kendall et al. 2007; Burgess et al. 2013). The investigations on modern carbonate sediments of the platform, however, have great advantage that environmental parameters can be directly measured, allowing to link sediment parameters to environmental (oceanographic and ecological) conditions. 
Therefore, modern analogue studies are helpful for understanding carbonate systems, establishing models and comparing interpretations with those in the rock record. Examples of the platforms or shallow continental shelves with modern day carbonate precipitation include the Bahamas, the Florida platform, Yucatan peninsula, the platform on which the Great Barrier Reef (GBR) is growing, the Maldives atolls, the Persian Gulf and hypersaline lagoons and bays around Australia (Halley et al. 1983; Gillispie 2013). These modern carbonate systems have been extensively studied for the processes and factors that influence carbonate growth and/or demise and for the reconstruction and interpretation of ancient carbonate deposits. The purpose of this paper is to review the genetic aspects of various carbonate components (limestones, dolomites, ooids, phosphorites, Halimeda bioherms and lime muds) deposited during the Late Quaternary on the platform off western India and compare with those in the modern and ancient carbonate systems and suggest that the sediments on the platform serve as analogues for the ancient platform carbonates. Further, there has been an increase in the discovery of extensive microbial activity in deposits associated with modern and ancient microbial carbonate systems (Griffin and Awramik 1989; Summons et al. 2013). Cyanobacteria are the driving force for the vast majority of microbialites and presumably this was the case throughout the most geological time. By studying the genesis of Late Quaternary deposits on the platform, the role played by microbes can also be verified.

\section{Study area}

A carbonate platform lies at depths between 60 and $90 \mathrm{~m}$ on the outer continental shelf off western India (figure 1). It is located off the Narmada and Tapi rivers that debouch abundant water and terrigenous sediments (Rao 1975). This platform is separated from the mainland by a huge clastic depocenter - the Dahanu depression, in which, pro-delta sediments were extensively deposited (figure 1) since the Eocene (Basu et al. 1980). Petroleum occurs in the deeper Miocene strata of the platform and is being exploited in the present day. The sediment filled Dahanu depression is the present-day inner shelf. The amazing aspect and uniqueness of the platform come from abundant carbonate sedimentation with only $<10 \%$ terrigenous material, despite its location in the proximity of major rivers. The surficial sediments on the platform comprise various type of carbonate deposits of Late Quaternary age. Rao and Wagle (1997) reviewed the genesis of authigenic, carbonate and detrital sediments deposited on the entire continental shelf off western India. Scientific articles published after 1997 were more informative regarding the genesis of various carbonate deposits, especially on the platform. Therefore, the present review focuses only on genetic aspects of sediments on the carbonate platform and adjacent shelf and provide evidence that they serve as analogues of ancient platform carbonates.

\section{Sedimentary rocks}

Nair (1971), Nair et al. (1979) and Rao and Nair (1992) investigated and described various types of limestones (figure 1) from the carbonate platform and adjacent shelf. Coarse components such as ooid-peloids, faecal pellets, benthic foraminifers or shell fragments were present in these limestones. There is no significant change in the coarse components, but the cements that bind them showed significant variations. Cements are the diagnostic features of a particular environment and are fairly well known for each diagenetic environment, marine phreatic, fresh water vadose, fresh water phreatic conditions (Folk 1965; Bathurst 1975). Rao and Nair (1992) reported sub-tidal limestones on the western edge of the platform. Aragonite and high-magnesium calcite were carbonate minerals. Pellets and peloids were enclosed in a fine-grained, aragonite matrix. Cements were characterized by acicular and fibrous calcites and micrite of highmagnesium calcite (figure 2A) and are similar to those in sub-tidal limestones reported by MacInyre (1977) and Meyers (1978). Halimeda and faecal pellet-dominated limestones occur on the platform (Rao et al. 1994). Vadose diagenetic cements in the limestones are of two types (Schoeder 1973; Longman 1980). Aragonite with minor calcite were major carbonate minerals in these limestones. Solution stage vadose diagenetic cements were recognized by their porous nature and partly dissolved skeletals and pellets (figure $2 \mathrm{~B}$ ), whereas the precipitation stage vadose diagenetic cements were recognized by rim cements with rhombohedral crystals on grain surfaces, syntaxial overgrowth of calcite on skeletals (figure 2C), precipitation of calcite cements and blocky calcite crystals in the pore spaces (Rao and Nair 1992). 


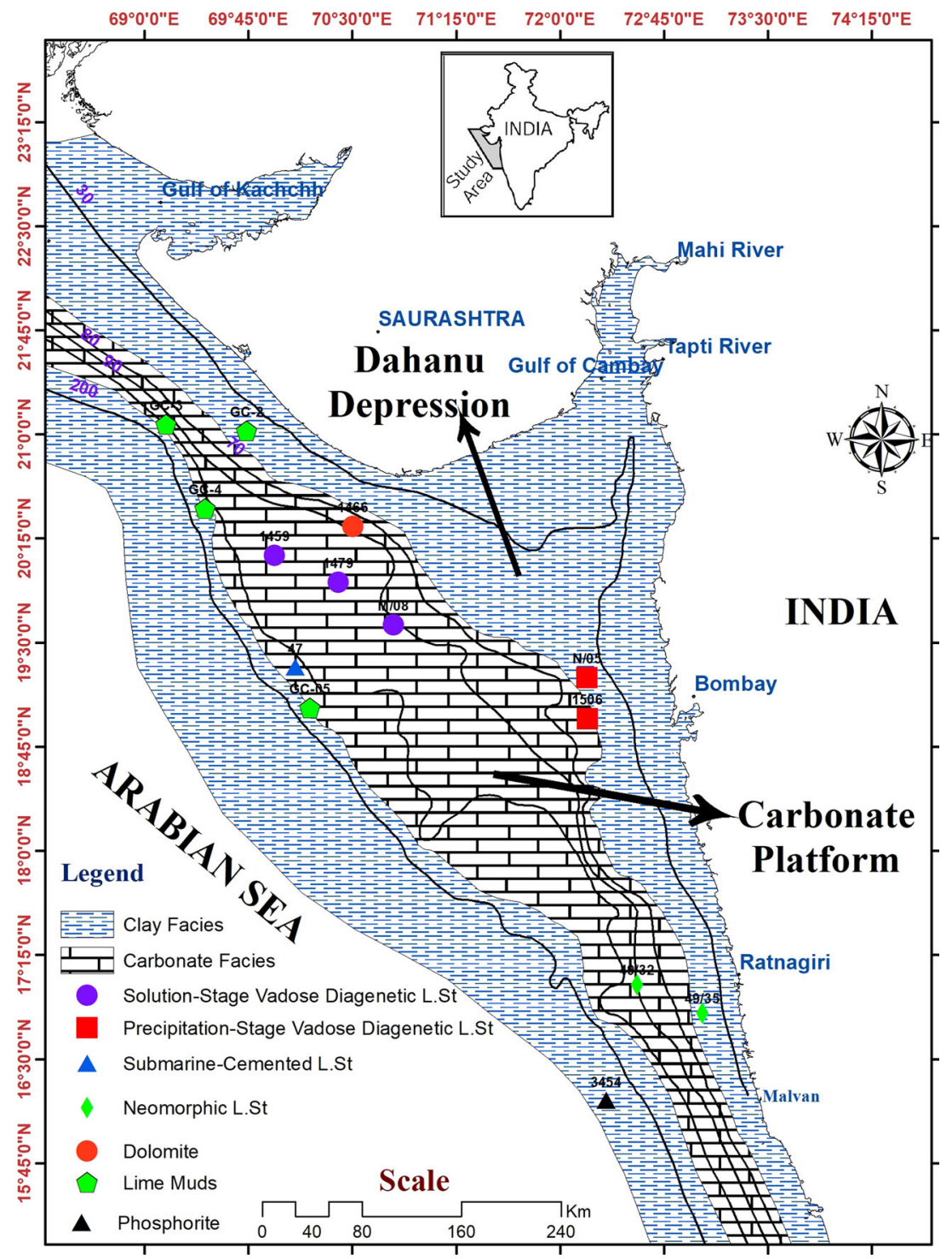

Figure 1. Location of the carbonate platform off western India. Locations of different types of limestones, such as submarinecemented, solution stage- and precipitation stage vadose diagenetic limestones and neomorphic limestones, dolomites, gravity cores (GC-1 to GC-6) in which lime muds recovered and phosphorites are also shown.

Limestones recovered from the continental shelf off Ratnagiri (figure 1) appear weathered. Contrastingly, low-magnesium calcite was the only carbonate mineral in these limestones. Coarse components were benthic foraminifers and a few faecal pellets. Cements occur in the form of microspar or pseudospar and pellets embedded were recrystallized and only faint out lines of evidence of their existence can be seen in some limestones (Rao and Nair 1992). In other limestones, the cements were characterized by recrystallized molds of grains and skeletal material, relic fibrous structures in large calcite crystals and inclusions in bladed calcite (figure 2D). These types of cements were interpreted as neomorphic cements (Longman 1980; Maliva 1995) and indicate that the sediments were subjected to neomorphic diagenetic changes that took place in the presence of meteoric waters. In other words, the pre-existing marine cemented limestones were sub-aerially exposed and the cements as well as coarse components were transformed into low-magnesium calcite in fresh water phreatic conditions. These limestones were formed during the lowered sea levels in Pleistocene when the shelf was exposed to subaerial conditions. The exact time when the shelf exposed during the Pleistocene cannot be ascertained because, the original carbonate skeletals and cements associated with limestones were recrystallized and there is no way to get them dated. Terrestrial limestones such as caliche pisolites (Rao 1990) and dune-associated calcretes, rhizoliths and 


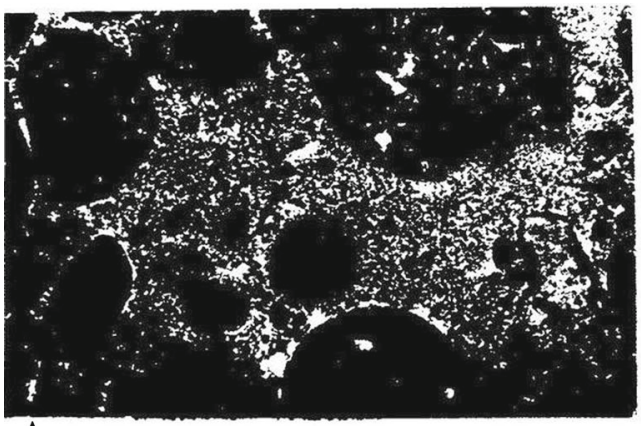

A

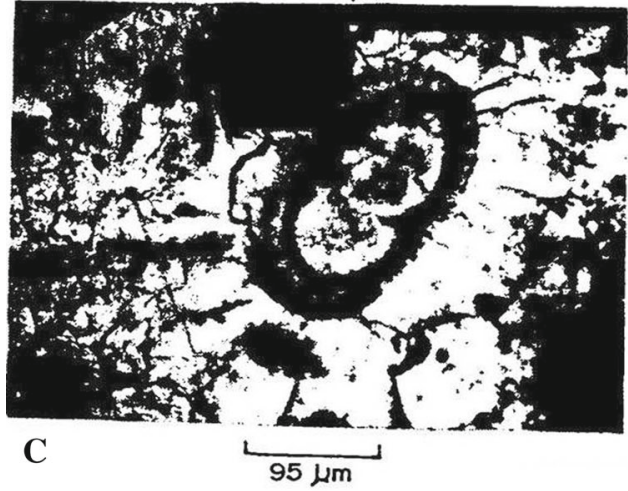

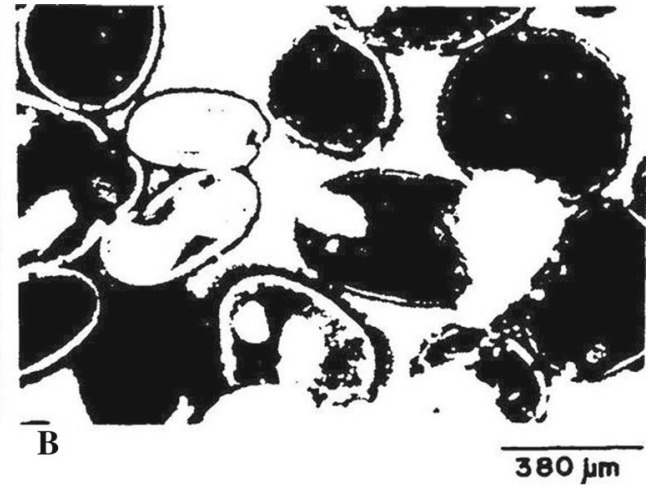

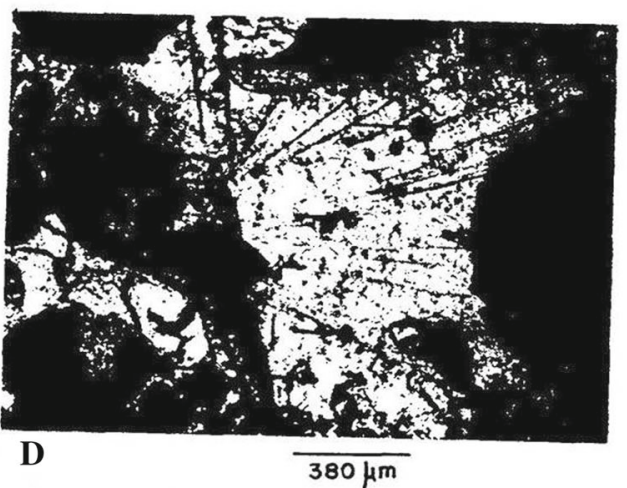

Figure 2. Photographs showing characteristic cements associated with different limestones. (A) sub-tidal cements, (B) solution stage vadose diagenetic cements, (C) precipitation stage vadose diagenetic cements and (D) neomorphic cements (figures taken from Rao and Nair 1992).

paleosols (Rao and Thamban 1997) were also reported on the continental shelf south of the platform.

Different types of limestones indicate that they were formed at different environmental conditions and times on the platform during the Late Quaternary. Sub-marine cemented and, solution stage- and precipitation stage vadose diagenetic limestones were radiocarbon dated (Rao and Nair 1992) and their occurrence on the platform implies sub-tidal and inter-tidal conditions of the platform during the Late Pleistocene-Holocene sea level transgression. Neomorphic limestones on the adjacent shelf (figure 1) indicate that the shelf was exposed to freshwater phreatic conditions during the lowered sea levels in Pleistocene. Neomorphic limestones were older than the sub-marine cemented and vadose diagenetic limestones. Absence of neomorphic limestones on the platform could be due to sample bias or were buried because of subsequent carbonate sedimentation during the Late Pleistocene-Early Holocene transgression. Sampling at close intervals on the platform is required to confirm the same. Limestones with different diagenetic cements have been reported in several platforms and continental shelves associated with low sedimentation rate (Bathurst 1975; Longman 1980; Maliva 1995).

\section{Late Pleistocene dolomites}

Dolomite is a common component in ancient and modern carbonate platforms. It is more stable at surface temperature and pressure than either aragonite or calcite. Modern dolomites differ from the ancient ones at least in two aspects: (a) dolomites are unequally distributed through time and occur in far greater quantity in ancient environments as compared to minor amounts in modern carbonate environments, and (b) the platform carbonates in ancient times, especially those in the Precambrian (Grotzinger and James 2000) and Cambrian (Wright 1997), have been strongly influenced by the activities of microbial systems and comprise cyanobacterial mat stromatolites (Valdiya 1972) and suggest biogeochemical processes supporting a genetic link between sulfate-reducing bacteria and dolomite precipitation. Contrastingly, modern dolomites occur in a wide variety of settings from lacustrine to sub-tidal to deep-sea environments and models proposed for their formation also 

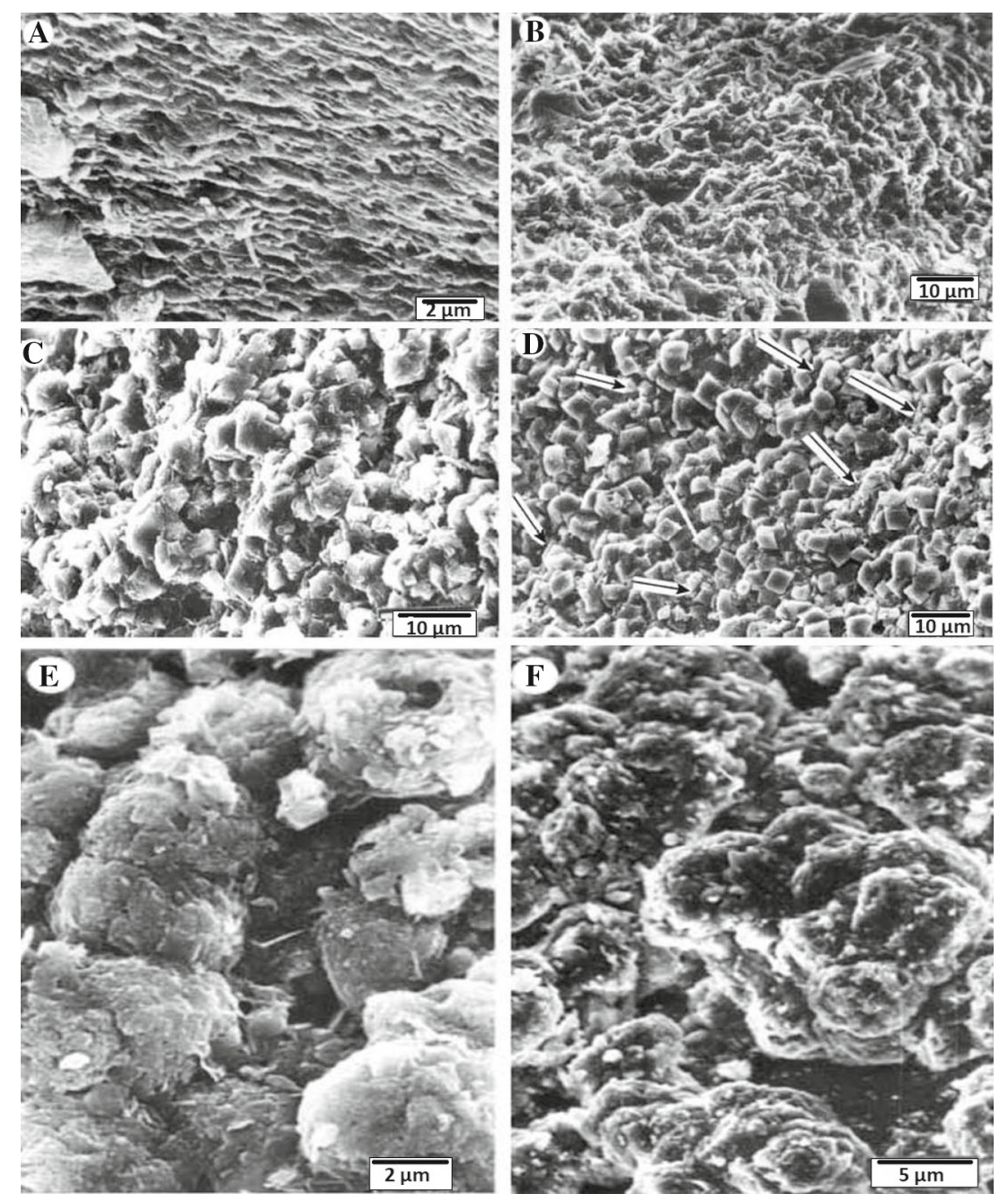

Figure 3. SEM photographs of dolomites. (A-B) sub-micron sized, stacked tubular laminae and contorted tubules interspersed with bioclastic detritus, (C) dolomite crystals adhered to the filaments (D) microfabric consisting of dolomite crystals with faint outlines of microlaminae (arrows), (E) hollow ovoid-type globular bodies arranged in straight chains and (F) dolomitized colonies of bacteria in the form of rosettes (figures taken from Rao et al. 2003a).

vary (Patterson and Kinsman 1982; Machel and Mountjoy 1986; Hardie 1987; Mitchel and Land 1987; Rosen and Coshell 1992; Rao et al. 2003a and references therein). It is often hypothesized chemical mediation for the formation of recent dolomites from shallow settings. Further, many theories have been advanced for dolomite formation in different environments but no one of them has been universally accepted. The problem of the origin of dolomite and explanation for its unequal distribution through time - known as 'dolomite problem' (Van Tuyl 1916; Arvidson and Mackenzie 1999) are still debated. Therefore, it is questionable whether the modern dolomites are analogues for their ancient ones. Recent investigations based on laboratory and field studies, however, proposed microbial mediation for dolomite formation
(Vasconcelos et al. 1995; Warthmannn et al. 2000; Wright 2000).

Dolomites from the carbonate platform off western India occur as dark grey crusts. Both thin sections and SEM studies of the crusts indicate the presence of well-preserved, stacked dolomitized tubular laminae interspersed with bioclastic detritus (figure 3A), contorted dolomite tubules (figure 3B), dolomite crystals adhered onto microlaminae (figure $3 \mathrm{C}$ and $\mathrm{D}$ ) and hollow, 1-3 $\mu \mathrm{m}$ sized ovoid-type globular bodies arranged in straight chains (figure 3E) and forming rosettes (figure 3F). These have been interpreted as polygenic assemblage of mat-forming microorganisms of probable cyanobacterial affinity (Rao et al. 2003a). The microstructures reported in our dolomites are similar to dolomite stromatolites, 
wherein dolomite precipitation is a metabolic product of mat-forming microorganisms, largely cyanobacteria. Dolomite encrustations on tubules (figure 3C) and overgrowth of dolomite on celllike structures suggest that dolomite formation continued on the sheath during early diagenesis. Microcrystalline dolomite fabric with few relics of microorganisms (figure 3D) are interpreted to record progressive and continued mineralization of organic sheath. These studies indicate that dolomite is a bio-mineral and biogeochemical processes are involved in its formation (Rao et al. 2003a).

High-magnesium calcite (HMC), dolomite, pyrrhotite and marcasite were present in the order of abundance in these crusts. The intimate association of sulfide minerals with microbial laminae suggests that dolomitization of microbial laminae occurred in anoxic, sulphate-reducing environments. High $\delta^{18} \mathrm{O}$ of dolomite $(4.1 \%$ ) in our dolomites (Rao et al. 2003a), similar to the presentday dolomites in tropical, hypersaline lagoons of Lagoa, Brazil (Vasconcelos and McKenzie 1997), suggests hypersaline conditions for dolomite precipitation. Positive $\delta^{13} \mathrm{C}$ values of $\operatorname{HMC}(2.5 \%$ ) and dolomite $(0.9 \%)$ than in the carbonates precipitated during organic diagenesis suggest that carbonates pool during dolomitization may have derived from both organic matter and dissolution of carbonate detritus. Dolomitized microbial mats (figure $3 \mathrm{~A}$ and $\mathrm{B}$ ) and cell-like microstructures (figure $3 \mathrm{E}$ and $\mathrm{F}$ ) suggest that dolomitization is a rapid early diagenetic process, wherein microbes played a major role in their formation (Rao et al. 2003a). Modern dolomites in the hypersaline lagoons, Lagoa, Vermelha, Brazil (Vasconcelos et al. 1995; Vasconcelos and McKenzie 1997), and lacustrine environments from the Coorag region, Australia (Von der Borch and Lock 1979; Wright 2000) and laboratory studies using sulphate-reducing bacteria from lagoonal sediments (Warthmannn et al. 2000) demonstrated possible involvement of benthic microbial communities in the precipitation of dolomite.

Dolomites from the platform are of Late Pleistocene age and represent a rare example of primary precipitation of dolomite by biogeochemical processes. These dolomites are in contrast with the more commonly reported processes secondary replacement and dolomitization of limestones or chemical precipitation. Dolomites from the carbonate platform (Rao et al. 2003a), many ancient dolomites (Valdiya 1972; Grotzinger and
James 2000) and newly reported recent dolomites (Vasconcelos et al. 1995; Warthmannn et al. 2000; Wright 2000) suggest that the micro-organisms and microbial processes played important roles in their formation and thus the dolomites of Late Pleistocene age reported here serve as analogues for the ancient ones.

\section{Halimeda bioherms}

Bioherm is an organic reef of mound-like form built by a variety of marine invertebrates, including corals, echinoderms, mollusks, green algae and others. Halimeda is a genus of green macroalga from the phylum Chlorophyta. Halimeda bioherms are large reef-like or mound-like geological structures formed by the growth of Halimeda. Halimeda species is capable of producing extensive biohermal calcareous sediment accumulations and commonly found in tropical oceans around the world (Multer 1988) and are considered as carbonate producing factories (Pomar and Hallock 2008). Aragonite is the predominant mineral in these deposits.

The calcareous sediment produced by Halimeda is known to occur only from the Cretaceous onward (Hillis-Colinvaux 1980; Hillis 1997). Except a few recently reported ancient bioherms, the Paleozoic phylloidal algal mounds in the Sacramento mountains (Kirkland et al. 1993) and Miocene mounds of Sorba Basin, SW Spain (Braga and Martin 1993; Braga et al. 2015), Halimeda bioherms do not have rich fossil record. The mound-building activity of Halimeda was, however, well recognized since 1978 in several deposits formed during the Late Pleistocene-Holocene sea level transgression and Holocene in the Indo-Pacific region (Orme et al. 1978; Roberts et al. 1987; Hine et al. 1988; Liddell et al. 1988; Marshall and Davies 1988; Searle and Flood 1988; Rao et al. 1994; Heyward et al. 1997; Xu et al. 2015). The limited fossil record of Halimeda mounds and several Holocene occurrences hint at specific climatic and environmental conditions responsible for their favored growth and preservation. Rao et al. $(1994,2018)$ investigated carbonate sand buildups on the carbonate platform and identified Halimeda bioherms formed during the Late Pleistocene-Holocene transgression and specified the environmental conditions responsible for their growth and demise.

Detailed bathymetric studies on the platform revealed linear and laterally coalesced pinnacles in the form of mounds, well-developed large 


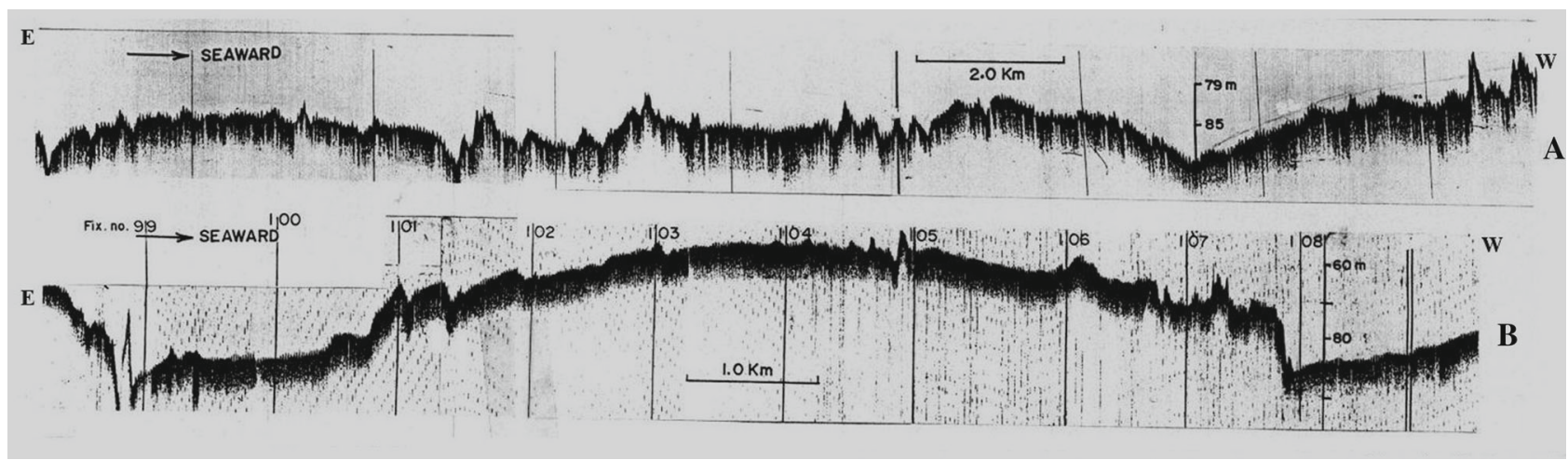

Figure 4. Bathymetry of the carbonate platform showing (A) coalesced ridges in the form of small mounds and (B) elongated broad mounds, characteristic of Halimeda bioherms (figures taken from Rao et al. 2018).

lens-shaped mounds (figure $4 \mathrm{~A}$ and $\mathrm{B}$ ), ridges and banks (Nair 1975; Vora and Almeida 1990; Rao et al. 2018). These features were $2-6 \mathrm{~m}$ high landward and up to a height of $20 \mathrm{~m}$ seaward to the platform. Seismic data indicate that these mounds were transparent with no rigid internal structure and can be defined as Halimeda bioherms. Sediments everywhere on the platform were predominantly aragonite sands (Nair and Pylee 1968; Nair and Hashimi 1981; Rao and Wagle 1997). Thin sections of the sands exhibit their internal structures that indicate most of the sands were Halimeda grains (figure 5A), followed by faecal pellets (figure 5B) and a few ooids and peloids (Rao et al. 1994). On the basis of bathymetry and sediments, Rao et al. (1994, 2018) interpreted that the Halimeda bioherms on the platform produced abundant carbonate sands and mud and, the mud was subsequently fixed by Crustaceans as faecal pellets and peloids. The age of the carbonate sands mostly ranges between 11 and 7.5 ka BP and is presumed as the growth period of Halimeda bioherms. Rao et al. (2018) suggested that the nutrients brought by upwelling currents are responsible for their luxuriant growth. The growth of bioherms stopped after $7.5 \mathrm{ka} \mathrm{BP}$ on the platform and subsequently became drowned, like many other drowned carbonate platforms common in the geological record. In tropical regions sea level changes are expected to be less dramatic and an order of magnitude slower than the average carbonate production rate (Eberli 1991). Similarly, little subsidence occurs on passive margins. Therefore, these factors are obviously not sufficient to drown the healthy platforms. It is suggested that a combination rather than a single factor is necessary to terminate platform growth (Eberli 1991). Environmentally stressed conditions

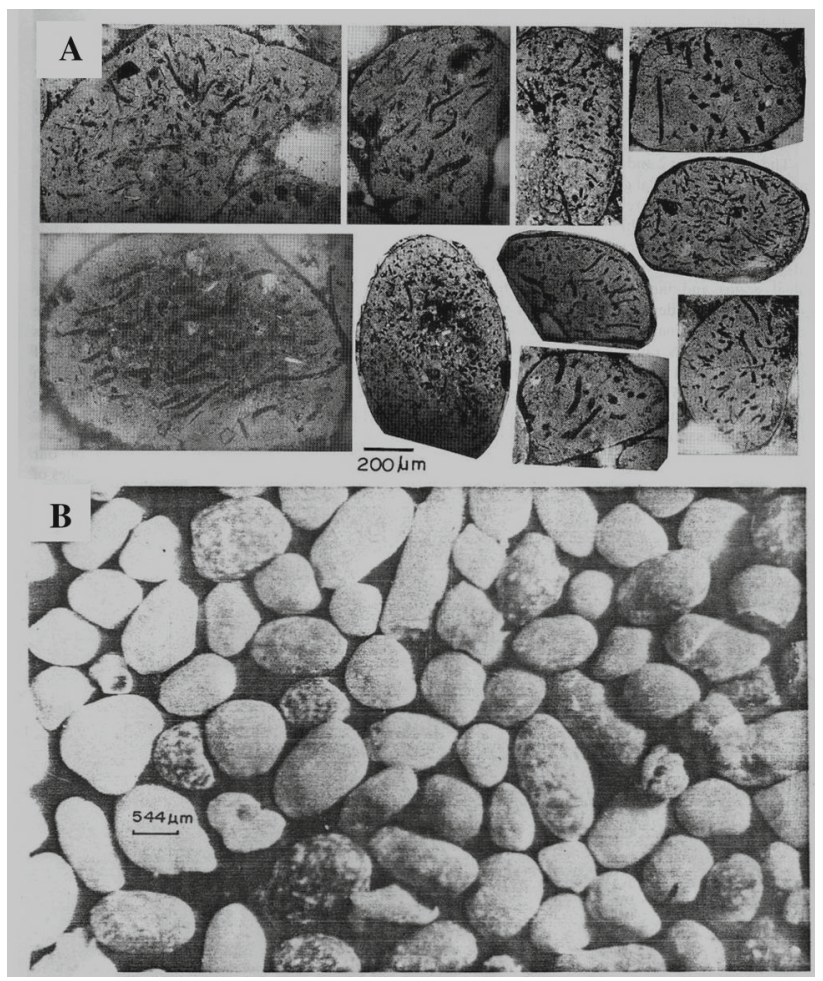

Figure 5. (A) Halimeda grains and (B) faecal pellets (figures taken from Rao et al. 1994).

would be easier to drown the platforms. It is possible that a change in climatic conditions may have resulted in excess availability of nutrients (Hallock and Schlager 1986) that produces blooms of heterotrophic organisms, which in turn reduce the growth of reefs and carbonate secreting benthos. It is therefore suggested that the shift in upwelling centers and sea level changes after $7.5 \mathrm{ka}$ BP may have led to their demise (Rao et al. 2018). These authors also estimated the mass calcium carbonate content on the platform as $1.8 \mathrm{Gt}$, comparable with that on the Great Barrier Reef during the Holocene. Halimeda bioherms are few in the 
ancient geological history. However, the bioherms reported here resemble the Late Pleistocene and Holocene bioherms in the Indo-Pacific region and thus serve as Late Quaternary analogues. Detailed investigations are required to quantitatively evaluate the mass calcium carbonate content on the platform with additional data on shallow seismic studies and long sediment cores.

\section{Lime muds}

Fine grained carbonate sediments or sedimentary rocks are reported from Precambrian to Recent in many carbonate platforms or continental shelves around the world. Ancient carbonate deposits with abundant lime muds are source of significant petroleum reserves in the Arabian Gulf (Kendall et al. 2007). Lime muds with high organic matter content have been reported in Recent sediments from the Bahamas and Arabian Gulf. Source rock analyses of carbonate mud demonstrate that the muds trap abundant organic matter, which might have generated large volumes of its oil. Carbonate mud sediments therefore are future source beds for the hydrocarbons (Kendall et al. 2007).

Isolated platforms in shallow water environments are dynamic systems and produce enough sediments to build vertically to sea level and prograde laterally over its slopes (Gischler and Zingeler 2002). Moreover, the sediments deposited are strongly influenced by energy conditions of the overlying water, caused by waves, currents and storms. A large portion of fine-grained carbonate sediments (lime muds) generated on the platform are often exported to the adjacent lagoons or slope (James et al. 2005), and coarse sediments are usually retained on the platform. The origin of fine grained sediments/sedimentary rocks is unclear in many ancient carbonate deposits and important to understand their source for constructing depositional model. Aragonite-dominated lime muds are formed inorganically in the Persian Gulf and the Bahamas even in the present day.

Two basic concepts are debated abundantly in the literature regarding the origin of lime muds (Wells and Illing 1964; Stockman et al. 1967; Neumann and Land 1975; Kendall et al. 2007; Rao et al. 2012 and references therein): (a) lime muds are primarily the result of postdisintegration of several species of calcifying green algae and biological and mechanical breakdown of other calcareous skeletal, (b) aragonite muds

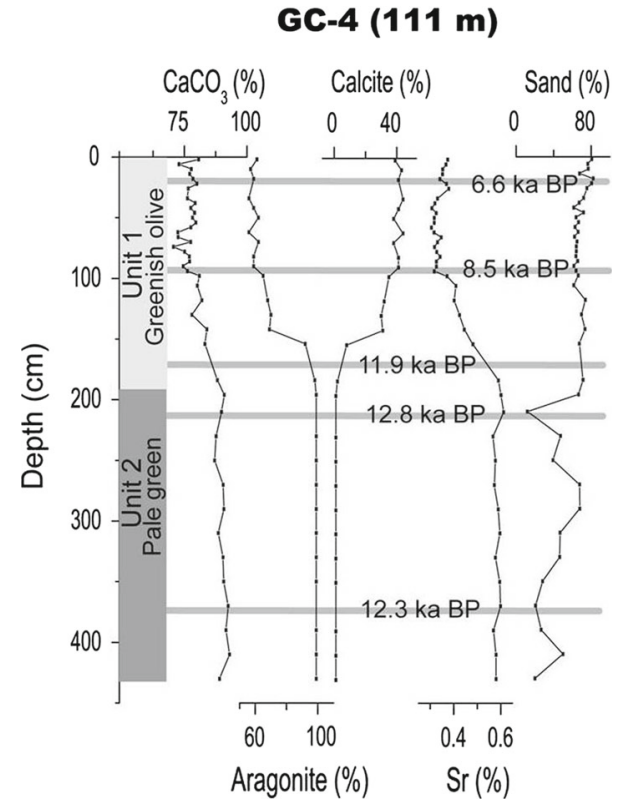

Figure 6. Geochemical characteristics of sediments in gravity core (GC-4), showing lime muds in the lower portion of the core (figure taken from Rao et al. 2012).

are inorganically precipitated directly from the water column (whitings) in shallow environment. Investigations revealed whitings (dense lime suspensions) are abundant both in the Arabian Gulf and the Bahama banks. Radioisotopes, especially short-lived isotopes of the whitings support instantaneous character of white precipitation in the water column (Robbins and Blackwelder 1992; Kendall et al. 2007). Some whitings in the Bahamas may be the result of microbial carbonate precipitation (Yates and Robbins 1999) or physical agitation by storms or suspended from the bottom because of physical phenomena (Shinn et al. 1989).

The lime muds occurring in sediment cores ( $\mathrm{GC}-$ 1 to $\mathrm{GC}-5$; figure 1) recovered at depths between 56 and $121 \mathrm{~m}$ on the continental shelf off the Gulf of Kachchh and carbonate platform off western India were investigated for their origin. The muds were confined to the lower portions of gravity cores, while their upper portions were terrigenous sediments suggesting relict nature of lime muds (figure 6). The total carbonate and aragonite contents of the lime mud-dominated sediments on the shelf cores were lower (60-75\% and up to 80\%) than those on the platform slope $(90-95 \%$ and $>95 \%$, respectively; figure 6), suggesting that the lime muds on the shelf were contaminated with higher proportions of terrigenous material. The lime mud comprises of broken fragments of shallow water carbonate skeletals and bioclasts on the shelf and ovoid to spherical microparticulates of aragonite on 


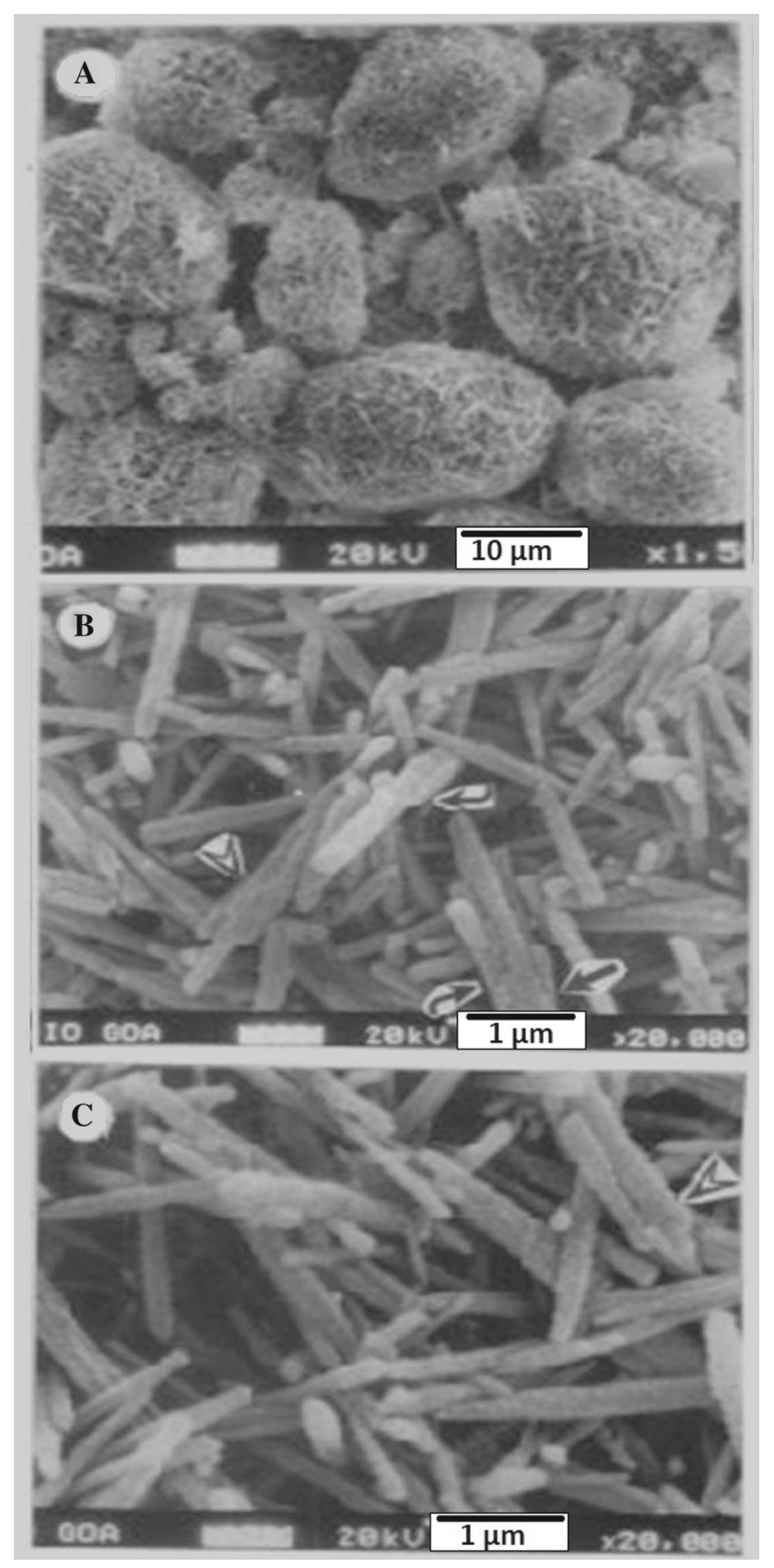

Figure 7. SEM photographs of lime muds showing (A) cemented micrites and $(\mathbf{B}-\mathbf{C})$ acicular aragonite needles apparently disintegrated from Halimeda plates (figures taken from Rao et al. 2012).

the platform (figure 7A), suggesting that the shelf muds are detrital-derived and platform muds are diagenetically formed in lime muds.

On the basis of the Sr content of lime muds one would know the sources of $\mathrm{Sr}$ in lime muds. The lime muds from the Bahamas (0.72-1.06\%), Abu Dhabi $(0.94 \%)$ and inorganically formed aragonite needles $(>0.85-1.0 \%)$ exhibit high $\mathrm{Sr}$ values and were formed by inorganic processes (Dix 2001). Similarly, the corals and Codiacean algae have higher Sr content $(0.63-0.86 \%)$ and are referred to as high Sr skeletals (Dix et al. 2005). As the Sr content of lime muds from the platform slope ranged from 0.58 to $0.77 \%$ lime muds might have been derived from the disaggregation of high $\mathrm{Sr}$ skeletals, rather than inorganically formed from the water column (Rao et al. 2012). This argument is supported by the $\mathrm{Sr} / \mathrm{Ca}$ ratios of lime muds (0.022 to 0.024$)$ that are close to that of Halimeda (0.024). The occurrence of heavily broken prismatic aragonite needles, jointed needles, rods emanating from the envelope of mineralized aragonite (see arrows in figure 7B and C) suggests that they were disintegrated from the soft tissues of algae. The stable isotope values were within the range for sedimentary aragonite needles. Rao et al. (1994, 2018) reported abundant Halimeda bioherms formed during the Early Holocene. The platform sediments showed the presence of well-rounded Halimeda grains whose size is much smaller than that of Halimeda plates, indicating that the plates were disintegrated and the muds thus produced were exported to shelf break during high-energy conditions. In other words, the lime muds were biodetrital and disintegrated from Halimeda and then transported to the slope of the platform.

\section{Ooids}

Ooids are small $(<2 \mathrm{~mm})$, spheroidal and concentrically laminated sedimentary grains, usually composed of calcium carbonate but sometimes composed of iron and phosphate-based minerals. They are typically limited to tropical coastal settings. Numerous investigations revealed ooids or oolitic strata or oolitic-peloidal sediments are common throughout the geological history from Precambrian onward (Simone 1980) and mostly formed in shallow sea level conditions and active water circulation on carbonate platforms and bank tops (Kindler and Hearty 1996). Ooids display wide range of grains as nucleus and consist of tangential and radial fibrous microstructures in the cortex.

Two aspects of the ooids, (a) microstructure and mineralogy and (b) origin are discussed widely in the literature to understand whether the Late Quaternary and modern ooids (see references in table 1) are analogues for their ancient counter parts. Similar to dolomites and lime muds, ooids occur abundantly in ancient carbonate deposits and in lesser quantities in Late Quaternary and 
Table 1. Characteristics of the Late Quaternary and modern ooids in different regions of the World Ocean.

\begin{tabular}{|c|c|c|c|c|c|}
\hline $\begin{array}{l}\text { Area of } \\
\text { occurrence }\end{array}$ & $\begin{array}{l}\text { Depth } \\
(\mathrm{m})\end{array}$ & Age & Mineralogy & Microstructures & References \\
\hline The Amazon Shelf & $80-150$ & Late Pleistocene & $\begin{array}{l}\text { High-magnesium } \\
\text { calcite (HMC) }\end{array}$ & Radial & 1 \\
\hline The Bengal Shelf & $120-130$ & Late Pleistocene & $\mathrm{HMC}$ & Radial & 2 \\
\hline $\begin{array}{l}\text { The Great Barrier } \\
\text { Reef }\end{array}$ & $80-150$ & Early Holocene & $\mathrm{HMC}$ & Radial & 3 \\
\hline The Georgia Shelf & $35-150$ & Late Pleistocene & Aragonite & Tangential & 4 \\
\hline $\begin{array}{l}\text { The Eastern margin } \\
\text { of India }\end{array}$ & $80-150$ & $\begin{array}{c}\text { Late Pleistocene-- } \\
\text { Early Holocene }\end{array}$ & Aragonite & & 5 \\
\hline $\begin{array}{l}\text { The Western margin } \\
\text { of India }\end{array}$ & $60-110$ & $\begin{array}{c}\text { Late Pleistocene-- } \\
\text { Early Holocene }\end{array}$ & Aragonite & $\begin{array}{l}\text { Tangential and } \\
\text { radial }\end{array}$ & $6,7,8$ \\
\hline $\begin{array}{l}\text { The Baffin Bay, } \\
\text { Texas }\end{array}$ & & Holocene & $\mathrm{HMC}$ & Radial & 9 \\
\hline The Gulf of Aqaba & $<5$ & Holocene & Aragonite & Radial & 10 \\
\hline The Shark Bay & & Holocene & Aragonite & Radial & 11 \\
\hline The Great Salt Lake & & Modern & Aragonite & Radial & 12 \\
\hline The Laguna Madre & $<5$ & Modern & $\begin{array}{l}\text { Aragonite }+ \\
\text { HMC }\end{array}$ & $\begin{array}{l}\text { Tangential and } \\
\text { radial }\end{array}$ & 13,14 \\
\hline The Bahamas & & Modern & Aragonite & Tangential & $15,16,17,18$ \\
\hline The Persian Gulf & & Modern & Aragonite & Tangential & 19 \\
\hline
\end{tabular}

1. Milliman and Barretto (1975), 2. Wiedicke et al. (1999), 3. Marshall and Davies (1975) 4. Pilkey et al. (1966) 5. Subbarao (1964), 6. Von Stackelberg (1972), 7. Nair et al. (1979), 8. Rao and Milliman (2017), 9. Land et al. (1979), 10. Friedman et al. (1973), 11. Davies (1970), 12 Sandberg (1975), 13. Rusnak (1960), 14. Freeman (1962), 15. Illing (1954), 16. Newell et al. (1960), 17. Milliman (1967), 18. Folk and Lynch (2001), 19. Loreau and Purser (1973).

modern deposits. Differences occur in mineralogy of the ooids, which are always calcitic in ancient limestones and, both aragonitic and calcitic in modern and Holocene ooids (table 1). Mineralogy and microstructure of the ooids are strongly influenced by sea water chemistry, $\mathrm{Mg} / \mathrm{Ca}$ ratio, atmospheric $\mathrm{CO}_{2}$ partial pressure and carbonate saturation state. Similarly, microstructures in the cortex portions of the ooids are different. For example, the ancient ooids exhibit only radial fibrous microstructures, whereas the Recent/Holocene ooids exhibit co-existence of radial and tangential microstructures (Simone 1980). Bladed/radial microstructures in ooids from different localities and environments were interpreted as a result of algal precipitation, quiet water deposition, diagenesis and hyper-salinity (Logan et al. 1969; Friedman et al. 1973; Davies and Martin 1976; Fabricius 1977). One needs to realize that modern marine settings are not always the best analogues for ancient carbonates. Since the Recent/ Holocene ooids are least altered diagenetically, their detailed microstructure would be helpful to distinguish whether microstructures are primary or secondary and possible factors that controlled their formation.
Ooids have been reported in Late Pleistocene-Holocene and modern sediments on the continental shelves and platforms in the world ocean (table 1), including Indian margins (Subbarao 1964; Naidu 1967; Nair 1971; Von Stackelberg 1972; Wiedicke et al. 1999; Rao and Milliman 2017). Numerous models discussed the origin of ooids, especially, whether they are exclusively chemical precipitates (Milliman 1974; Davies et al. 1978) or formed by organo-mineralization (Trichet and Desfarge 1975; Reitner et al. 1997; Davies et al. 1978) or whether microbes involved in their formation (Folk and Lynch 2001; Duguid et al. 2010). There is still no consensus as to the formation of ooids, despite biogenic origin of ooids has been progressed in recent years (Gillispie 2013; Summons et al. 2013; Rao and Milliman 2017). Abiotic or inorganic models involve precipitation in suspension in supersaturated, agitated water. These models, however, fail to account for the high organic matter content in the ooids. Biotic models involve ooids colonized by a defined microbial community and microbes possibly mediated calcification of cortical layers. Ooids are intimately associated with stromatolites in ancient carbonates. Recent studies, however, demonstrate 


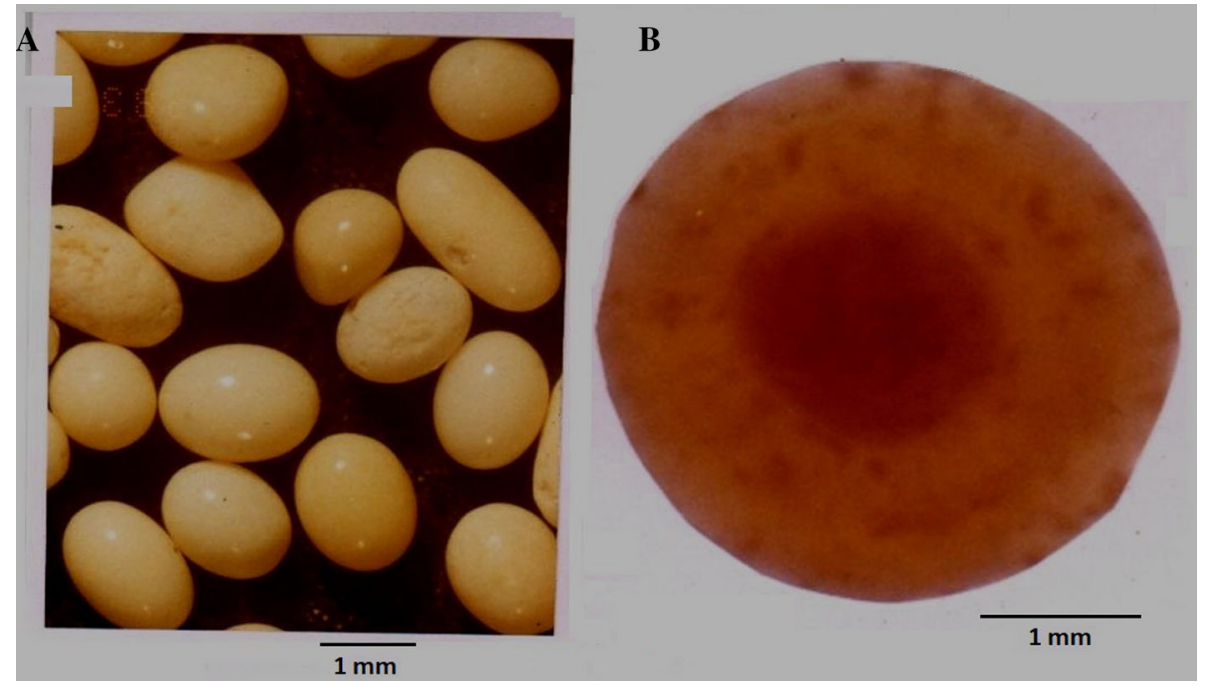

Figure 8. (A) Ooids and (B) section of ooid showing thick coating at cortex portions.

that at a few locations, such as the Hamelin pool, a hypersaline basin in western Australia and Pleistocene Bahamas ooids are intimately associated with stromatolites (Summons et al. 2013) favouring biotic origin of ooids and in varied environmental settings. Recent works tend to recognize close analogues between the ancient and Recent ooids.

The Late Quaternary ooids from the carbonate platform off western India (figure 8) were investigated for their mineralogy, microstructure and origin (Rao and Milliman 2017). These ooids came from 14 stations, representing the entire platform. Ooids were tan coloured at landward (figure 8A) and white seaward of the platform. Aragonite was the only carbonate mineral in ooids at all stations. They found that the thickness of the cortex varied from $<5$ to $200 \mu \mathrm{m}$ (figure $8 \mathrm{~B}$ ). Using scanning electron microscopy, they showed that the concentric/tangential microstructures were ubiquitous in the cortex which, in turn, were made up of individual layers that range from 1 to 20 $\mu \mathrm{m}$ (figure 9). The tangential laminae further displayed multiple straight or contorted tubules stacked upon one another (figure 9A and B) resembling encrusted organic filaments with their diameter ranging from microalgae to bacteria (figure 9A and $\mathrm{E}$ ). The individual laminae elsewhere in the cortex (figure 9E) are extensively mineralized and coated with nanospheres or ellipsoids (figure 9F), which have been described as nanobacteria by Folk and Lynch (2001). Rao and Milliman (2017) suggested that the algal/bacterial filaments were periodically encrusted on available nucleus and then mineralized into discrete laminae. The algal/ bacterial filaments usually have mucillagenous sheath organic matter of variable thickness. They emphasized that the microorganisms associated with decaying organic sheath during early diagenesis were responsible for mineralization of the individual laminae. Rao and Milliman (2017) suggested microbial origin for the cortex portions of ooids, rather than chemical precipitation.

Rao and Milliman (2017) also reported bladed/radial microstructures as discontinuous structures in the cortex of the ooids or below microbial filaments (figure 9C and D) and suggested that these microstructures are not primary but formed subsequently. They showed radial fibers on tangential laminae and argued that these are secondary and microfabrics are controlled by the nature of organic substances associated with the sheaths. In summary, the ooids were biogenic in origin and microorganisms associated with decaying organic matter in the encrusted/bacterial filaments during early diagenesis were responsible for mineralization of individual laminae in the cortex. Diagenetic alteration probably resulted in radial microstructures and stable calcite in ancient ooids and therefore different from the Holocene and modern ooids.

Recent investigations on modern ooids in the Shark Bay, Australia (a hypersaline basin) indicate the presence of high organic matter, which in turn are composed of straight chain, saturated fatty acids and long-chain fatty ketones (Gillispie 2013). The $\delta^{13} \mathrm{C}$ values of ooid cortex fall between -12 and $-30 \%$ finger print of 

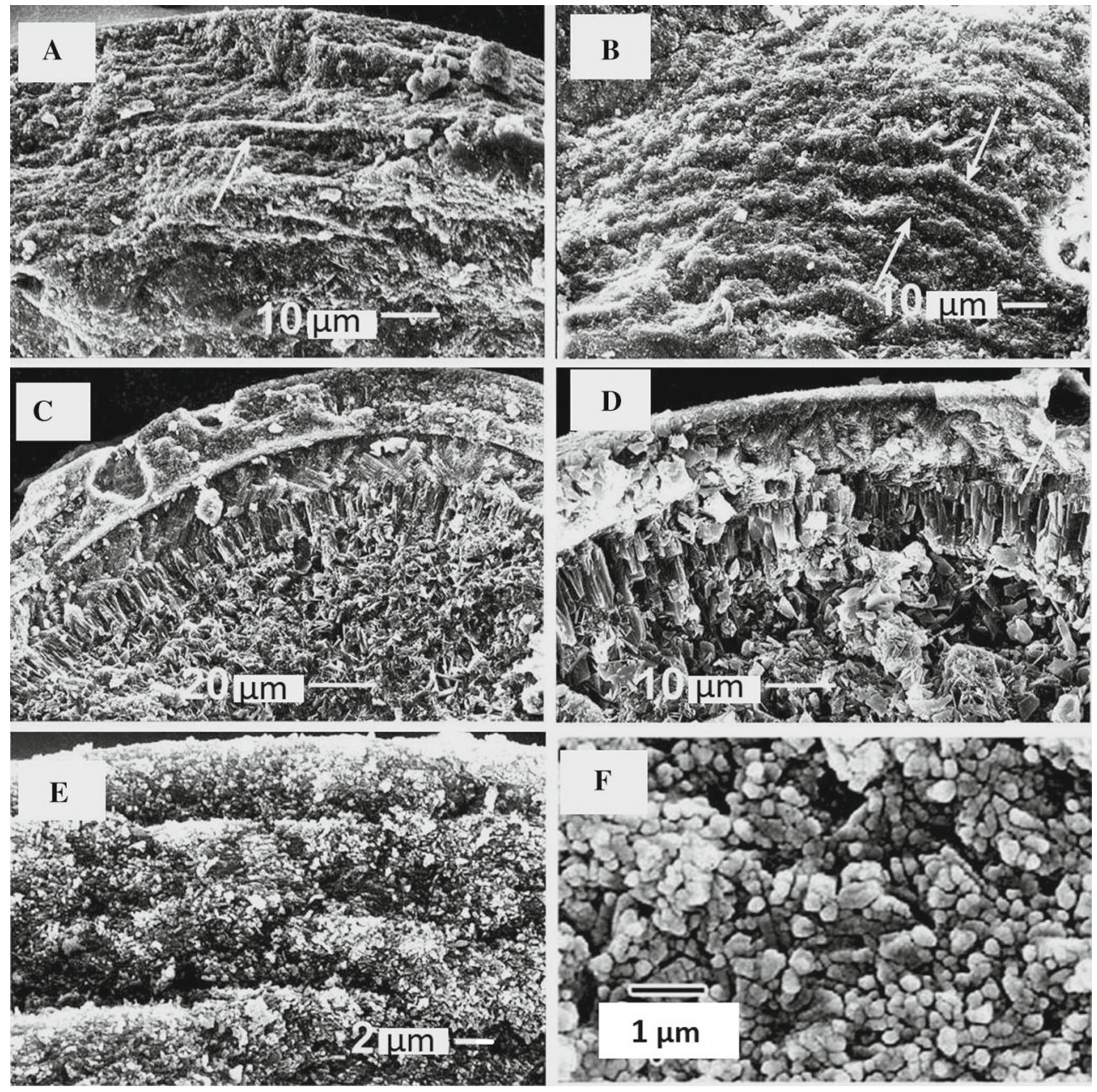

Figure 9. SEM photographs at cortex portions of the ooids showing (A-B) sub-micron size mineralized microbial laminae and contorted laminae stacked one upon another, (C-D) larger diameter mineralized laminae indicating that the laminae belong to algae. (E) Closer view of the microlaminae indicating its hollow nature and (F) sub-micron size particles described as nanobacteria on the surface of the laminae (figures taken from Rao and Milliman 2017).

the complex microbial community that lives close proximity to the growing ooids. The results suggest that the consortium of microbes alter the microenvironment of growing ooids in such a way that stimulates carbonate precipitation and protect ooids from dissolution. Summons et al. (2013) reported a large fraction of lipids abound to carbonate matrix and lipids were being incorporated continuously during ooid growth. They reported elemental sulfur, which forms exclusively by microbial processes in the extracts indicating an origin from sulfatereducing bacteria. The ooids of Jurassic age also revealed the preservation of hydrocarbons as well as appreciable amounts of fatty acids indicating that the ooids preserve organic bio-signatures. Further, the comparison of biomarkers from ooids from different environmental conditions and preservation state will provide insight into syngenetic molecular signals of environmental conditions and biological activity in ancient oolites (Mariotti et al. 2015; O'Reilly et al. 2017).

\section{Phosphorites}

Phosphorites, similar to carbonate deposits, occur abundantly in ancient sedimentary deposits, but a few phosphorite occurrences are reported in the modern day. Numerous stromatolitic phosphorites have been reported during Precambrian-Cambrian (Cook and Shergold 1986), Mesozoic (Follmi 1996) and Eocene (Soudry and Panczer 1994) times and phosphate stromatolites in Quaternary (Rao et al. 2000a). Extensive reworking and/or benthic microbial communities might have played a major role in their formation. Modern phosphorite deposits 

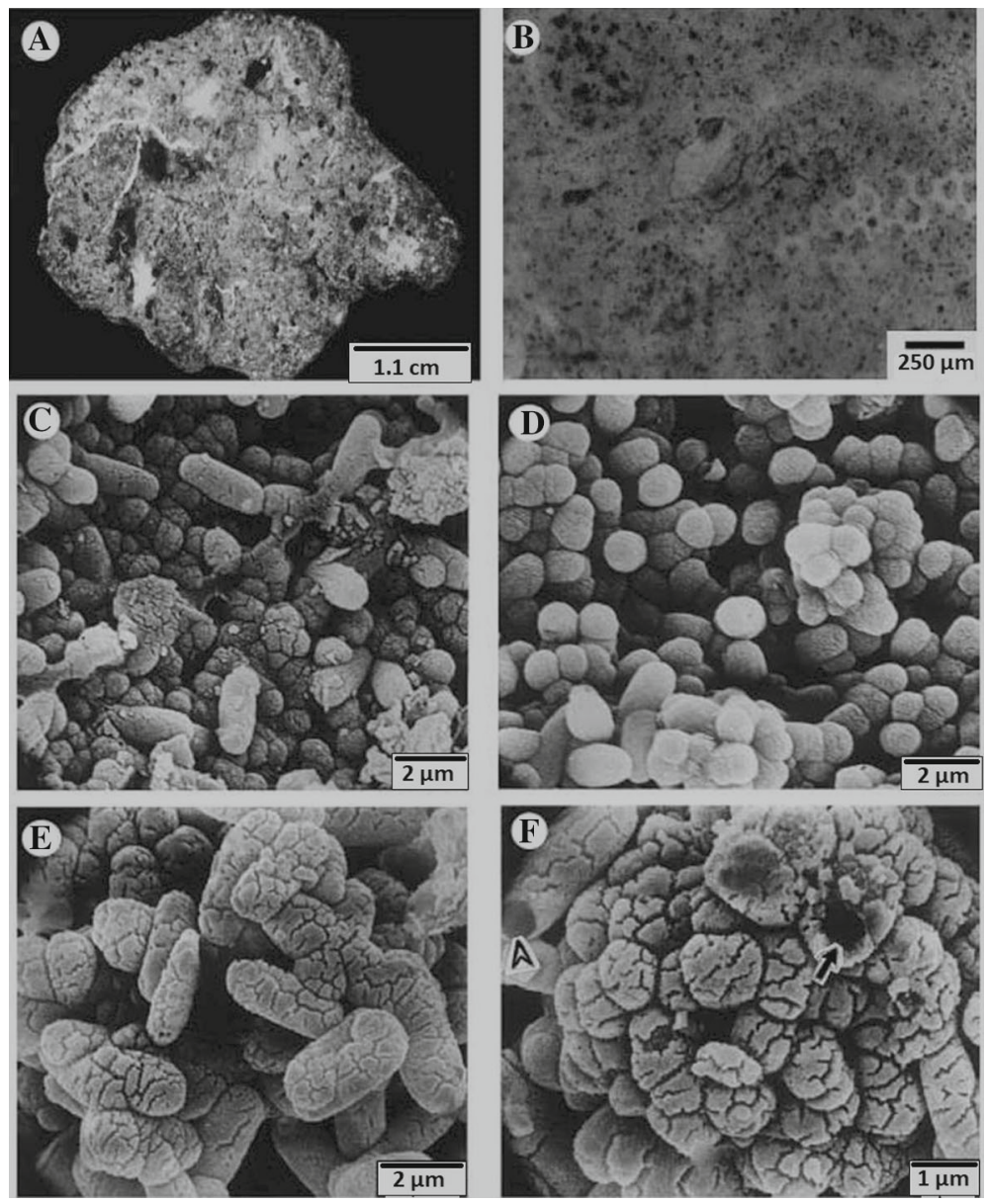

Figure 10. Phosphorites (A) phosphorite nodule, (B) thin section of phosphorite showing that the carbonate mud and skeletal are being replaced by phosphate, (C-D) phosphate microparticles in the form of rod and ovoid type particles resembling phosphatized bacteria and $(\mathbf{E}-\mathbf{F})$ colonies of mineralized bacteria. Microparticles are hollow and sheath organic matter associated with bacteria acted as substrate for phosphate mineralization (figures taken from Rao et al. 2000b).

are smaller in size and occur as scattered nodules and pellets at the sediment-water interface (within the top few centimetres of sediments) and at or near to the boundary of the oxygen-minimum zone (Burnett 1977; Baturin 1982; Glenn et al. 1994). Most of the modern phosphorites occur on western margins associated with upwelling (Kazakov 1937; Burnett and Riggs 1990) but a few occur in the eastern margins of the continents (O'Brien et al. 1981). The sources of phosphorus for modern phosphorites have been presumed to be sedimented plankton organic matter, fish debris, and the iron redox cycle phosphate pump (Jarvis et al. 1994; Follmi 1996). Microbial mediation in phosphorite formation was suggested even for modern phosphorites (O'Brien et al. 1981; Rao and Nair 1988; Lamboy 1990).

Phosphorites, phosphatised limestones and phosphate-glaucony grains of Late PleistoceneHolocene age have been reported on the western margin of India (Baturin 1982; Nair 1985; Rao and Nair 1988; Rao et al. 1990, 1993, 2000b; Rao and Lamboy 1995, 1996) and also on its eastern margin (Rao et al. 2000a). However, high-grade phosphorites as phosphorite nodules (figure 10A) and grains occur within the upper few centimetres of lime muds on the continental slope, adjacent to the carbonate platform (figure 1; Rao et al. 2000b). They occur at a depth of $232 \mathrm{~m}$ and within the present-day oxygen minimum zone. Carbonates, fluorapatite and calcite were major minerals in these phosphorites. The phosphorite consists of light-brown microcrystalline apatite containing a few skeletal fragments and planktonic foraminifera. Thin sections showed evidence of dissolution of skeletal calcite or mud and filling of the resulting cavities by phosphate (figure 10B). Phosphatization seems to have occurred through replacement of abundant micrite. Scanning electron microscope (SEM) studies further showed microbial filaments 
and rod-shaped apatite particles of about $2-3 \mu \mathrm{m}$ in length, which are constricted at one end and appeared hollow and, ovoid-shaped apatite particles of about $1-2 \mu \mathrm{m}$ in diameter (figure 10C and E). The ovoid particles join together into club-shaped particles or globose forms or rosettes (figure 10F). Similar apatite particles and particle aggregates have been described as fossilized phosphate bacteria and colonies of microbial cells by several workers, both in older and present day phosphorites and phosphatised limestones and phosphate-glaucony grains (O'Brien et al. 1981; Mullins and Rasch 1985; Southgate 1986; Rao and Nair 1988; Soudry and Lewy 1988; Lamboy 1990; Breheret 1991; Krajewski et al. 1994; Rao and Lamboy 1995). Rao et al. (2000b) discussed the genesis of apatite in high-grade phosphorites and suggested replacement of carbonate by apatite and the direct precipitation of carbonate fluorapatite by microbial mediation. It is further suggested that microbes are instrumental in determining environmental conditions ( $\mathrm{pH}$ and $\mathrm{Eh}$ ) favourable for the dissolution of calcite and precipitation of phosphate, and microbes act as substrates for phosphate mineralization as sheath phosphate. Rao et al. (2000b) suggested that phosphatization was subsequent to the demise of carbonates on the platform and lime muds, oxygen minimum conditions and upwelling favoured the formation of phosphorites on the continental slope and both replacement of carbonate by phosphate and microbial processes played major role in their formation. Recent phosphorites from Peru and Cretaceous phosphorites from France formed by the similar processes and thus our phosphorites serve as analogues to them.

\section{Evidences of neotectonic activity during Late Pleistocene and Holocene}

Several workers proposed Late Pleistocene and Holocene sea level changes and neotectonic activity along the western margin of India, including the carbonate platform (Nair 1971; Nair et al. 1979; Rao and Nair 1992; Hashimi et al. 1995; Rao and Veerayya 1996; Rao et al. 1996, 2003b, c; Rao and Milliman 2017). The Holocene sea level curve proposed by Hashimi et al. (1995) is only an imaginary curve and cannot be used as a reference sea level curve for the western margin of India, as the points making the curve are 'inferred ages' and, actual radiocarbon dated samples fall away from the curve. Several other points have also been raised and cautioned users to realize serious short comings in making the curve and stop using it (Rao et al. 1996, 2000b; Rao and Veerayya 1996; Rao and Milliman 2017). We highlight 3 points to show evidences of Late Quaternary neotectonic activity on and around platform: (1) dolomites occur at $64 \mathrm{~m}$ depth on the platform (figure 1) and detailed investigations indicate direct precipitation of dolomite in the form of dolomite stromatolites in hypersaline and anoxic conditions in lagoons. The age of dolomite measured by accelerated mass spectrometer (AMS) method was 17,750 $\pm 80 \mathrm{yr}$ and corresponds to the last glacial maximum (LGM; $18,000 \mathrm{yr}$ BP $)$. The age and depth $(64 \mathrm{~m})$ at which dolomites occur on the platform do not correspond to the age and sea level position $(-120 \mathrm{~m})$ at LGM. This implies neotectonic activity and subsidence of the platform during or after dolomite formation (Rao et al. 2003a). However, we agree that more data are required to substantiate this point.

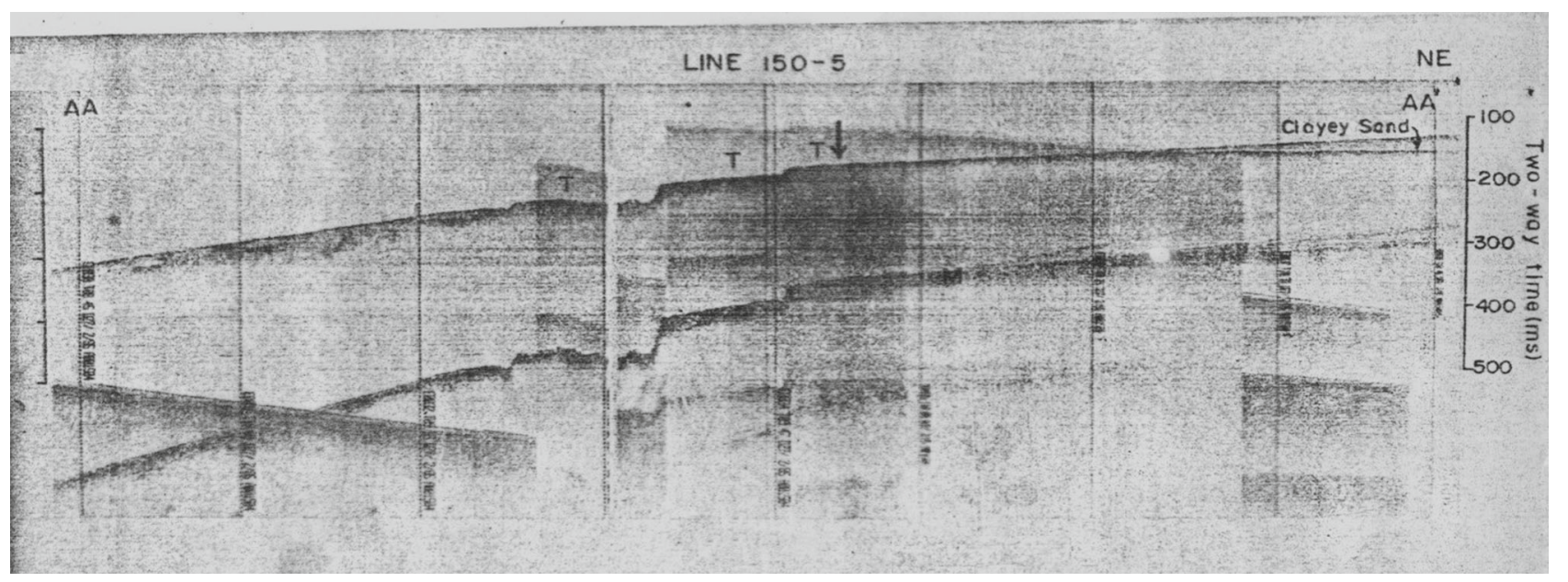

Figure 11. Bathymetry at the edge of the platform showing submarine terraces $(T)$ at deeper depth. Terraces at 130,145 and $170 \mathrm{~m}$ are shown in the figure (taken from Rao and Veerayya 1996). 
(2) Submarine terraces are important geomorphic features on the continental margins and may record former sea levels still stands. Nair (1975) and Rao and Veerayya (1996) reported submarine terraces on the seaward slope of the platform at depths of 35 and $170 \mathrm{~m}$ and relict reef structures at 370$392 \mathrm{~m}$ deep (figure 11). The terraces at depths between 120 and $35 \mathrm{~m}$ on the platform were suggested to record sea level still stands that occurred during the course of glacio-eustatic sea level rise (Nair et al. 1979). The terraces deeper than $120 \mathrm{~m}$ and up to $170 \mathrm{~m}$ on the platform slope (figure 11) are difficult to interpret because the maximum sea level low was $-120 \mathrm{~m}$ during LGM. The deeper depth terraces probably suggest neotectonic activity and subsidence after LGM. This inference is also supported by the oolitic limestones collected on the terrace at $130 \mathrm{~m}$ depth (Rao and Veerayya 1996). The petrology of the limestones indicates that these limestones were formed at inter-tidal depths and the calibrated ${ }^{14} \mathrm{C}$ age of the limestones was $11,900 \mathrm{yr} \mathrm{BP}$; this implies that the $130 \mathrm{~m}$ depth terrace was at intertidal depths at $\sim 12,000 \mathrm{yr}$ BP (Rao and Veerayya 1996). The eustatic sea level, however, was at $-90 \mathrm{~m}$ at 12,000 yr BP. This disparity of depth by $\sim 40 \mathrm{~m}$ indicates subsidence

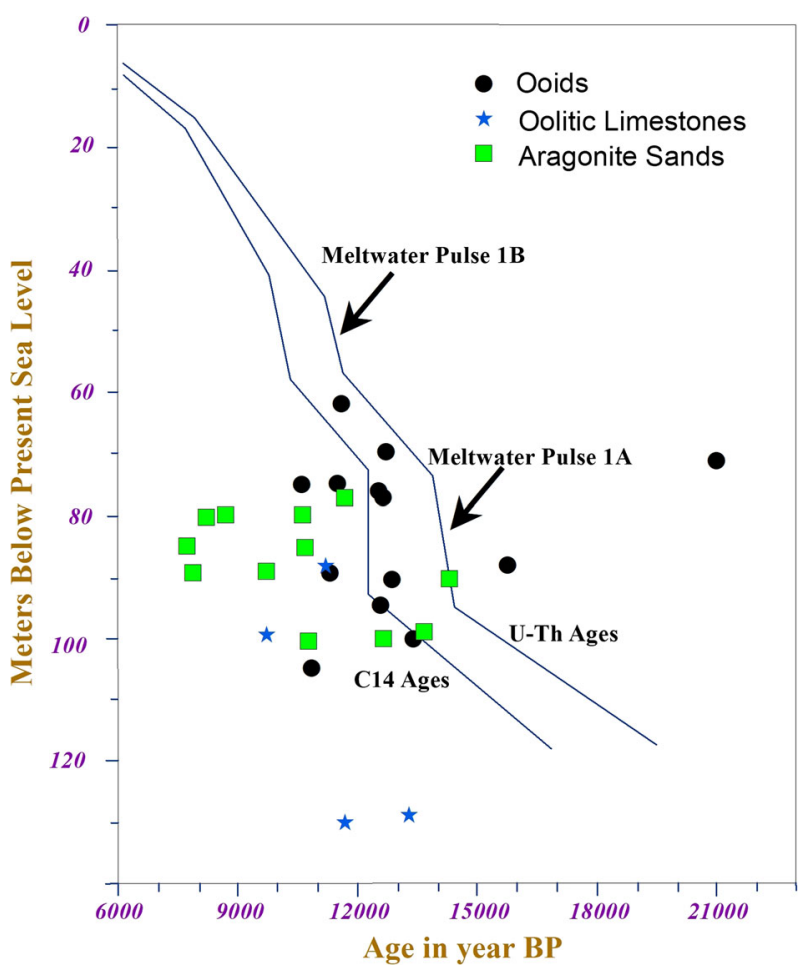

Figure 12. Plot of calibrated ages of ooids on the platform vs. depth on the Barbados sea level curve (Bard et al. 1990). Data taken from Rao and Veerayya (1996), Rao et al. (2003b), Rao and Milliman (2017) . of the platform, sometime after $12 \mathrm{ka}$ BP. (3) Our detailed study of ooids on the carbonate platform indicated biogenic origin. In other words, ooids may not have necessarily formed at or near to sea level. The calibrated ${ }^{14} \mathrm{C}$ AMS ages of ooids (Rao and Milliman 2017) and oolitic limestones (Nair et al. 1979) and their depth of occurrence on the platform were plotted on the sea level curve (figure 12) of Bard et al. (1990). Only ooids at two stations were plotted on the curve but those at other stations plot away or much away from the curve implying ooids on the platform were formed not at sea level but at deeper water depths. Therefore, ooids are not indicators of sea level. Similarly, the age and depth of aragonite sands (Rao et al. $2003 \mathrm{~b})$ plot parallel to the age-axis and that the minimum age of the sand was $7.5 \mathrm{ka}$ BP. It implies that the carbonate growth on the platform ceased after $7.5 \mathrm{ka}$ BP. This could be due to the environmental stress caused by excess nutrient availability and the platform drowned subsequently after 7.5 ka BP.

\section{Conclusions}

The carbonate platform located on the outer continental shelf of northwestern India comprises various carbonate components (limestones, dolomites, ooids, phosphorites, Halimeda bioherms and lime muds) formed during the Late Quaternary. The genetic aspects of these deposits were reviewed in relation to their ancient deposits. Submarine cemented and vadose diagenetic limestones on the platform and, neomorphic and terrestrial limestones on the continental shelf south of the platform indicate that the neomorphic limestones were probably buried on the platform because of subsequent carbonate sedimentation. Dolomites on the platform are primary deposits, resemble dolomite stromatolites, wherein dolomite is precipitated by the metabolic activity of microorganisms, rather than dolomitization of carbonates or chemical precipitation. Microbial mediation is abundantly reported in the dolomites from ancient deposits. The ooids reported here demonstrate that they were formed by mineralization of microbial laminae enveloped by their cortical layers. Radial microstructures were formed by diagenesis. Variations in mineralogy and microstructures between the ancient ooids and modern ones could be due to diagenetic transformations in older ooids. Phosphorite formation was subsequent to the 
carbonate sedimentation and formed by microbial mineralization of organic matter and replacement of carbonate by apatite. Evidence of mineralized microbes and microbial activity in the dolomites, ooids and phosphorites of Late Quaternary age suggests that these deposits are genetically related to their ancient counter parts and thus serve as Quaternary analogues for the ancient deposits. We could not answer why were dolomites, ooids and phosphorites occur abundantly in ancient deposits but a few occurrences in modern days. Evidences are ever increasing in favour of microbial role in mineral formation, both in ancient and modern carbonate systems (Griffin and Awramik 1989) and, microbial involvement becomes an acceptable mechanism for sedimentary mineral formation in different environments. Awramik et al. (1976) reported changes in fossil morphotypes of microbiota through Precambrian to modern times and modern microbial mats composed of communities of cyanophytes, eucaryotic algae, fungal structures and photosynthetic bacteria. Gillispie (2013) reported complex microbial communities and consortium of microbes in the present-day microbial systems. We therefore suggest changes in morphotypes of microbial communities and microenvironments through time are responsible for variations in their abundance. In recent years, biomarkers are being used to identify organic bio-signatures in ancient deposits. Further research on biomarker studies will answer the role of microbes and microbial environments more clearly in mineral formation.

Halimeda bioherms do not have rich fossil record in the Earth's ancient history but the bioherms reported here were similar to those formed in the Late Pleistocene-Holocene transgression in the Indo-Pacific region. Lime muds resemble fine-grained limestones in ancient times. Lime muds were bio-detrital and formed from the disintegration of bioherms and skeletal components. Evidences of Late Quaternary neotectonic activity on the platform were presented. More data are required to better understand sea level changes and neotectonics activity on the platform.

\section{Acknowledgements}

We wish to thank the Vice-Chancellor, Vignan's University for facilities and encouragements. V P Rao wishes to thank senior colleagues R R Nair, M Veerayya and B G Wagle and Ph.D students
M Thamban, Pratima Kessarkar and A Anil Kumar, who shared VPR's research work on carbonates of the platform at the CSIR-National Institute of Oceanography, Goa.

\section{References}

Arvidson R S and Mackenzie F T 1999 The dolomite problem: control on precipitation kinetics by temperature and saturation state; Am. J. Sci. 299 257-288.

Awramik S M, Margulis L and Barghoorn E S 1976 Evolutionary processes in the formation of stromatolites; In: Stromatolites (ed.) Walter M R, Amsterdam, Elsevier, Developments in Sedimentology 20 149-162.

Bard E, Hamelin B, Fairbanks R G and Zindler A 1990 Calibration of the ${ }^{14} \mathrm{C}$ timescale over the past 30,000 years using mass spectrometric U-Th ages from Barbados cores; Nature 345 405-410.

Bathurst R G C 1975 Carbonate sediments and their diagenesis; Elsevier, Amsterdam, 658p.

Baturin G N 1982 Phosphorites on the sea floor: Origin, composition and distribution; Dev. Sedimentol. 33, 345p.

Basu D N, Banerjee A and Tamhane D M 1980 Source areas and migration trends of oil and gas in Bombay offshore basin, India; AAPG Bull. 64 209-220.

Braga J C and Martin J M 1993 Halimeda bioherms in Messinian basinal sequences: Fossil analogues of modern Australian examples; Abstracts, International Symposium on Alpine Algae, University of Munich, Munich.

Braga J C, Martin J M and Riding R 2015 Internal structure of segment reefs: Halimeda algal mounds in the Mediterranean Miocene; Geology 24 35-38.

Breheret J G 1991 Phosphatic concretions in black facies of the Aptian-Albianmarnes blues formation of the Vocontian basin (SE France) and at site DSDP 369: Evidence of benthic microbial activity; Cret. Res. 12 411-415.

Burgess P M, Winefield P, Minzoni M and Elders C 2013 Methods for identification of isolated carbonate buildups from seismic reflection data; AAPG Bull. 97 1071-1098.

Burnett W C 1977 Geochemistry and origin of phosphorite deposits from off Peru and Chile; GSA Bull. 88 813-823.

Burnett W C and Riggs S R 1990 Phosphate deposits of the world: Neogene to modern phosphorites; Cambridge University Press, Cambridge, UK, 464p.

Cook P J and Shergold J H 1986 Phosphate deposits of the world: Proterozoic and Cambrian phosphorites; Cambridge University Press, Cambridge, UK, 385p.

Davies G R 1970 Carbonate bank sedimentation, Eastern Shark Bay, western Australia; In: Carbonate Sedimentation and Environments, Shark Bay Western Australia (eds) Logan B W, Davies G R, Read J F and Cebulski D E, AAPG Memoir 13 85-168.

Davies P J and Martin K 1976 Radial aragonite ooids, Lizard Island, Great Barrier Reef, Queensland, Australia; Geology 4 120-122.

Davies P J, Bubela B and Ferguson J 1978 The formation of ooids; Sedimentology 25 703-730.

Dix G R 2001 Origin of Sr-rich magnesian calcite mud in a Holocene pond basin (Lee Stocking Island, Bahamas); J. Sedim. Res. 71 167-175. 
Dix G R, James N P, Kyser T K, Bone Y and Collins L B 2005 Genesis and dispersal of carbonate mud relative to Late Quaternary sea level changes along a distally steepened carbonate ramp (Northwestern Shelf, Western Australia); J. Sedim. Res. 75 665-678.

Duguid S M A, Kyser T K, James N P and Rankey E C 2010 Microbes and ooids; J. Sedim. Res. 80 236-251.

Eberli G P 1991 Growth and demise of isolated carbonate platforms: Bahamian controversies; In: Controversies in Modern Geology, Academic Press, London, pp. 231-248.

Eberli G P, Masaferro J L and Rick Sarg J F 2004 Seismic stratigraphic evolution of the Miopliocene-Pliocene Segitiga platform, East Indonesia: The origin, growth and demise of the isolated carbonate platform; $A A P G \mathrm{Mem}$ oirs 81 309-328.

Fabricius F 1977 Origin of marine ooids and grapestones; Acad. Des. Sci. Paris 7 1-113.

Folk R L 1965 Some aspects of recrystallization in ancient limestones; In: Dolomitisation and limestone diagenesis: A symposium (eds) Pray L C and Murray P C, SEPM Spec. Publ. 13 14-48.

Folk R L and Lynch F L 2001 Organic matter, putative nanobacteria and the formation of ooids and hard grounds; Sedimentology 48 215-229.

Follmi K B 1996 The phosphorous cycle, phosphogenesis and marine phosphate-rich deposits; Earth-Sci. Rev. 40 55124.

Freeman T 1962 Quiet water ooids from Laguna Madre, Texas; J. Sediment. Res. 32 475-483.

Friedman G M, Amiel A J, Braun M and Miller D S 1973 Generation of carbonate particles and laminites in algal mats- example from sea-marginal hypersaline pool, Gulf of Aqaba, Red Sea; AAPG Bull. 57 541-557.

Fulthorpe C S and Schlanger S O 1989 Paleo-oceanographic and tectonic settings of Early Miocene reefs and associated carbonates of offshore Southeast Asia; $A A P G$ Bull. 73 729-756.

Gillispie A L 2013 Organic matter preserved in modern ooids from Shark Bay and the Bahamas; MSc Thesis, Massachusetts Institute of Technology, MA, USA.

Gischler E and Zingeler D 2002 The origin of carbonate mud in isolated carbonate platforms of Belize, Central America; Int. J. Earth Sci. 91 1054-1070.

Glenn C R, Follmi K B, Riggs S R, Baturin G N, Grimm K A, Trappe J, Abed A M, Galli-Olivier C, Garrison R E, Ilyin A, Jehl C, Rohrlich V, Sadaqah R, Schidlowski M, Sheldon R E and Siegmund H 1994 Phosphorus and phosphorites: sedimentology and environment of formation; Eclogae Geol. Helv. 87 747-788.

Griffin K M and Awramik S M 1989 Gaint Bahamian stromatolites: A modern analog for what? In: Proceedings of the 4th symposium on the Geology of Bahamas, pp. 168174 .

Grotzinger J P and James N P 2000 Precambrian carbonates: Evolution and understanding; In: Carbonate sedimentation and diagenesis in the evolving Precambrian world (eds) Grotzinger J P and James N P, SEPM Spec. Publ. 67 $1-18$.

Halley R B, Harris P M and Hine A C 1983 Bank margin environments; In: Carbonate depositional environments (eds) Scholle P S, Behout G G and Moore C H, AAPG Memoir 33 463-506.
Hallock P and Schlager W 1986 Nutrient excess and the demise of coral reefs and carbonate platforms; Palaios 1 389-398.

Hashimi N H, Nigam R, Nair R R and Rajagopalan G 1995 Holocene sea level fluctuations on western Indian margin: an update; J. Geol. Soc. India 46 157-162.

Hardie L A 1987 Dolomitization: a critical view of some current views; J. Sed. Petrol. 57 166-183.

Heyward A, Pinceratto E and Smith L D 1997 Big bank shoals of the Timor Sea: An environmental resource atlas; Australian Institute of Marine Science and BHP Petroleum, Townsville, Australia.

Hillis L 1997 Coralgal reefs from a calcareous green alga perspective and a first carbonate budget; In: Proceedings of the 8th International Coral Reef Symposium, pp. 761-766.

Hillis-Colinvaux L 1980 Ecology and taxonomy of Halimeda: Primary producer of coral reefs; Adv. Mar. Biol. 17 1-327.

Hine A C, Hallock P, Harris M W, Mullins H T, Belknap D F and Jaap W C 1988 Halimeda bioherms along an open seaway: Miskito Channel, Nicaraguan Rise, SW Caribbean Sea; Coral Reefs 6 173-178.

Illing L V 1954 Bahamian calcareous sands; AAPG Bull. 38 $1-95$.

James N P, Bone Y and Kyser T 2005 Where has all the aragonite gone-Mineralogy of Holocene neritic cool water carbonates, southern Australia; J. Sedim. Res. 75 454463.

Jarvis I, Burnett W C, Nathan Y, Almbaydin F, Attia K M, Castro L N, Flicoteaux R, Hilmy M E, Husain V, Qutawna A A, Serjani A and Zanin Y N 1994 Phosphorite geochemistry: State-of-the-art and environmental concerns; Eclogae Geol. Helv. 7 643-700.

Kazakov A V 1937 The phosphorite facies and the genesis of phosphorites: Geological investigations of agricultural ores; Scientific Institute of Fertilizers and InsectoFungicides Transactions 142 95-113.

Kendall C G St C, Shinn G and Janson X 2007 Holocene cyanobacterial mats and lime muds: Links to middle east carbonate source rock potential; Search and Discovery Article, AAPG Annual Meeting, Long Beach, California, USA.

Kindler P K and Hearty P J 1996 Carbonate petrology as an indicator of climatic and sea level changes: New data from Bahamian Quaternary units; Sedimentology 43 381-399.

Kirkland B L, Moore C H Jr and Dickson J A D 1993 Well preserved aragonite algae (Eugonophyllum U'doteaceae) from the Pennsylvanian Holder Formation, Sacramento Mountains, New Mexico; Palaios 8 111-120.

Krajewski K P, Van Cappellen P, Trichet J, Kuhn O, Lucas J, Martin-Algarra A, Prevot L, Tewari V V, Gasper I, Knight R I and Lamboy M 1994 Biological processes and apatite formation in sedimentary environments; Eclogae Geol. Helv. 87 701-745.

Kusumastuti A, Van Rensbergen $\mathrm{P}$ and Warren J K 2002 Seismic sequence analysis and reservoir potential of drowned Miocene carbonate platforms in the Madura Strait, East Java, Indonesia; AAPG Bull. 86 213-232.

Kuznetsov V G 1997 Oil and gas in reef reservoirs in the former USSR; Petrol. Geosci. 3 65-71.

Lamboy M 1990 Microstructure of a phosphatic crust from a Peruvian continental margin: phosphatized bacteria and associated phenomena; Oceanol. Acta 13 439-451. 
Land L S, Behrens E W and Frishman S A 1979 The ooids of Baffin bay, Texas; J. Sedim. Petrol. 49 1269-1278.

Liddell W D, Ohlhorst S L and Boss S K 1988 The significance of Halimeda as a space-occupier and sedimentproducer, 1-750 m, North Jamaica; In: Proceedings of the 6th International Coral Reef Symposium.

Logan B W, Harding J L, Ahr W M, Williams J D and Snead R G 1969 Late Quaternary carbonate sediments of Yucatan shelf, Mexico; In:Carbonate sediments and reefs, Yucatan Shelf, Mexico (ed.) Logan B W, American Association Petroleum Geologists, Tulsa, Okla, pp. 5-128.

Longman M W 1980 Carbonate diagenetic textures from near surface diagenetic environments; $A A P G$ Bull. 64 461-487.

Loreau J-P and Purser B H 1973 Distribution and ultrastructure of Holocene ooids in the Persian Gulf; In: The Persian Gulf (ed.) Purser B H, Springer-Verlag, New York, pp. 279-328.

Machel H G and Mountjoy E W 1986 Chemistry and environment of dolomitization - A reappraisal; Earth-Sci. Rev. $\mathbf{2 3}$ $175-222$.

MacInyre I G 1977 Distribution of submarine cements in a modern Caribbean fringing reef, Galeta Point, Panama; J. Sedim. Petrol. 47 503-516.

Maliva R G 1995 Recurrent neomorphic and cement microtextures from different diagenetic environments, Quaternary to Late Neogene carbonates, Great Bahama Bank; Sedim. Geol. 97 1-7.

Mariotti G, O'Reilly S S, Winter A R, Neumann S A, Pruss S B, Bosak T, Klepac-cerag V, McDermott F and Summons R E 2015 Molecular evidence for a microbial role in ooid formation and preservation of molecular biosignatures in ancient oolite; Abstract B21C-0452, American Geophysical Union, Fall Meeting, San Francisco.

Marshall L F and Davies P J 1975 High-magnesium calcite ooids from the Great Barrier Reef; J. Sedim. Res. 45 285291.

Marshall J F and Davies P J 1988 Halimeda bioherms of the northern Great Barrier Reef; Coral Reefs 6 139-148.

Meyers W J 1978 Carbonate cements: Their regional distribution and interpretation in Mississippian limestones of southwestern New Mexico; Sedimentology 25 371-400.

Multer H G 1988 Growth rate, ultrastructure and sediment contribution of Halimeda incrassata and Halime damonile, Nonsuch and Falmouth Bays, Antigua, WI; Coral Reefs 6 179-186.

Milliman J D 1967 Carbonate sedimentation on Hogsty Reef, A Bahamian atoll; J. Sedim. Petrol. 37 658-676.

Milliman J D 1974 Marine carbonates; Springer-Verlag, Heidelberg, 375p.

Milliman J D and Barretto H T 1975 Relict magnesium calcite ooids and subsidence of the Amazon shelf; Sedimentology 22 137-145.

Mitchel J T and Land L S 1987 Modern marine dolomite cement in a north Jamaican fringing reef; Geology $15557-$ 560 .

Mullins H T and Rasch R F 1985 Sea floor phosphorites along the central California continental margin; Econ. Geol. 80 696-715

Naidu A S 1967 Radiocarbon date of an oolitic sand collected from the shelf off the east coast of India; Bull. Nat. Inst. Sci. India 38 467-471.
Nair R R 1971 Beach rock and associated carbonate sediments on the Fifty Fathom Flat, a submarine terrace on the outer continental shelf of Bombay; Proc. Indian Acad. Sci. Sect. B 73 148-154.

Nair R R 1975 Nature and origin of small scale topographic prominences on the western continental shelf of India; Indian J. Mar. Sci. 4 25-29.

Nair R R 1985 Holocene phosphorites of the western continental shelf of India; Bull. Nat. Inst. Ocean India 18 $273-279$.

Nair R R and Pylee A 1968 Size distribution and carbonate content of the sediments of the western shelf of India; Bull. Nat. Inst. Sci. India 38 411-420.

Nair R R and Hashimi N H 1981 Mineralogy of the carbonate sediments western continental shelf of India; Mar. Geol. 41 309-319.

Nair R R, Hashimi N H and Guptha M V S 1979 Holocene limestones of part of the western continental shelf of India; J. Geol. Soc. India 20 17-23.

Neumann A C and Land L S 1975 Lime mud deposition and calcareous algae in the Bight of Abaco, Bahamas: A budget; J. Sedim. Petrol. 45 763-786.

Newell N D, Purdy E G and Imbrie J 1960 Bahamian oolitic sand; J. Geol. 68 481-497.

O'Brien G W, Harris, J R, Milnes, A R and Veeh H H 1981 Bacterial origin of eastern Australian continental margin phosphorites; Nature 294 442-444.

O'Reilly S S, Mariotti G, Winter A R, Neumann S A, Matys E D, McDermott F, Pruss S B, Bosak T, Summons R E and Klepac-cerag V 2017 Molecular biosignatures reveal common benthic microbial sources of organic matter in ooids and grapestones from Pigeon Cay, The Bahamas; Geobiology 15 112-130.

Orme G R, Flood P G and Sargent G E G 1978 Sedimentation trends in the lee of the outer (ribbon) reefs, northern region of the Great Barrier Reef Province; Phil. Trans. Roy. Soc. London Ser. A 291 85-99.

Patterson R J and Kinsman D J 1982 Formation of diagenetic dolomite in coastal sabkha along Persian Gulf; AAPG Bull. 66 28-43.

Pilkey O H, Schnitker D, Pevear D R 1966 Oolites on the Georgia continental shelf edge; J. Sedim. Petrol. 36462 467.

Pomar L and Hallock P 2008 Carbonate factories: A conundrum of sedimentary geology; Earth-Sci. Rev. 87 134-169.

Rao K L 1975 India water wealth; Orient Longman, New Delhi, 255p.

Rao V P 1990 On the occurrence of caliche pisolites from the western continental of India; Sedim. Geol. 69 13-19.

Rao V P and Lamboy M 1995 Phosphorites from the Oman margin, ODP Leg 117; Oceanol. Acta. 18 289-307.

Rao V P and Lamboy M 1996 Genesis of apatite in the phosphatized limestones of the western continental shelf of India; Mar. Geol. 136 41-56.

Rao V P and Nair R R 1988 Microbial origin of phosphorites of the western continental shelf of India; Mar. Geol. 84 105-110.

Rao V P and Nair R R 1992 A re-evaluation of climatic conditions during the Pleistocene and Holocene from the western continental shelf of India: Evidences from petrography of limestones; In: Oceanography of the Indian Ocean (ed.) Desai B N, Acaemic Press, India, pp. 423-438. 
Rao V P and Thamban M 1997 Dune associated calcretes, rhizoliths and paleosols from the western continental shelf of India; J. Geol. Soc. India 49 207-306.

Rao V P and Veerayya M 1996 Submarine terrace limestones from the continental slope off Saurashtra-Bombay: Evidence of Late Quaternary neotectonic activity; Curr. Sci. $7136-41$.

Rao V P and Wagle B G 1997 Geomorphology and surficial geology of the western continental margin of India: A review; Curr. Sci. 73 330-350.

Rao V P and Milliman J D 2017 Relict ooids off northwestern India: Inferences on their genesis and Late Quaternary sea level; Sedim. Geol. 358 44-50.

Rao V P, Lamboy M and Dupeuble P A 1993 Verdine and other associated authigenic (glaucony, phosphate) facies from the sediments of the southwestern continental margin of India; Mar. Geol. 111 133-158.

Rao V P, Anil Kumar A, Naqvi S W A, Chivas A R, Sekar B and Kessarkar P M 2012 Lime muds and their genesis offnorthwestern India during the Late Quaternary; J. Earth Syst. Sci. 121 769-779.

Rao V P, Kessarkar P M, Krumbein W E, Krajewski K P and Schneider R J 2003a Microbial dolomite crusts from the carbonate platform off western India; Sedimentology 50 819-830.

Rao V P, Rajagopalan G, Vora K H and Almeida F 2003b Late Quaternary sea level and environmental changes from relic carbonate deposits of the western margin of India; Proc. Indian Acad. Sci. 112 1-25.

Rao V P, Montaggionni L, Vora K H, Almeida F, Rao K M and Rajagopalan G 2003c Significance of relict carbonate deposits along the central and southwestern margin of India for environmental and sea level changes; Sedim. Geol. 159 95-111.

Rao V P, Veerayya M, Nair R R, Dupeuble P A and Lamboy M 1994 Late Quaternary Halimeda bioherms and aragonitic faecal pellet-dominated sediments on the carbonate platform of the western continental shelf of India; Mar. Geol. 121 293-315.

Rao V P, Veerayya M, Thamban M and Wagle B G 1996 Evidences of neotectonic activity and sea-level changes along the western continental margin of India; Curr. Sci. 71 213-219.

Rao V P, Natarajan R, Parthiban G and Mascarenhas A 1990 Phosphatised limestones and associated sediments from the western continental shelf of India; Mar. Geol. 95 $17-29$.

Rao V P, Naqvi S W A, Kumar M D, Cardinal D, Michard A, Borole D V, Jacobs E and Natarajan R 2000a A comparative study of Pleistocene phosphorites from the continental slope off western India; Sedimentology 47 945960.

Rao V P, Rao K M and Raju D S N 2000b Quaternary phosphate stromatolites from the continental margin off Chennai, Southeast coast of India: Analogs of ancient phosphate stromatolites; J. Sedim. Res. 70 1205-1217.

Rao V P, Mahale V P and Chakraborty B 2018 Bathymetry and sediments on the carbonate platform off western India: Significance of Halimeda bioherms in carbonate sedimentation; J. Earth Syst. Sci. 127(8) 106.

Reitner J, Arp G, Thiel V, Gautret P, Galling U and Michaelis W 1997 Organic matter in Great Salt Lake ooids
(Utah, USA): First approach to a formation via organic matrices; Facies 36 210-219.

Roberts H H, Phipps C V and Effendi L 1987 Morphology of large Halimeda bioherms, eastern Java Sea (Indonesia): A side-scan sonar study; Geo-Mar. Lett. 7 7-14.

Robbins L L and Blackwelder P L 1992 Origin of whitings: A biologically induced non-skeletal phenomenon; Geology 20 464-467.

Rosen M R and Coshell L 1992 A new location of Holocene dolomite formation, Lake Hayward, Western Australia; Sedimentology 39 1062-1074.

Rusnak G A 1960 Some observations of recent oolites; J. Sedim. Petrol. 30 471-480.

Sandberg P A 1975 New interpretation of Great salt Lake ooids and of ancient non-skeletal carbonate mineralogy; Sedimentology 22 497-537.

Schoeder J H 1973 Submarine and vadose cements in Pleistocene Bermuda Reef rocks; Sedim. Geol. 10 179-204.

Searle D E and Flood P G 1988 Halimeda bioherms of the Swain Reefs- southern Great Barrier Reef; In: Proceedings of the 6th International Coral Reef Symposium, 92p.

Shinn E A, Steinen R P, Lidz B H and Swart P K 1989 Whitings: A sedimentological dilemma; J. Sed. Petrol. 59 $147-161$.

Simone L 1980 Ooids: A review; Earth-Sci. Rev. 16 319-355.

Soudry D and Lewy Z 1988 Microbially influenced formation of phosphate nodules and megafossil moulds (Negev, southern Israel); Palaeogeogr. Palaeoclimatol. Palaeoecol. 64 15-34.

Soudry D and Panczer G 1994 Stromatolitic phosphorites in the Eocene of the Negev (Southern Israel); In: Phanerozoic Stromatolites II (eds) Bertrand-Sarfati J and Monty C L V, Springer Science and Business Media, Dordrecht, The Netherlands, pp. 255-276.

Southgate P N 1986 Cambrian phoscrete profiles, coated grains, and microbial processes in phosphogenesis: Georgina Basin, Australia; J. Sedim. Petrol. 56 429441.

Stockman K W, Ginsburg R N and Shinn E A 1967 The production of lime mud by algae in south Florida; J. Sedim. Petrol. 37 633-648.

Subbarao M 1964 Some aspects of continental shelf sediments off the east coast of India; Mar. Geol. 1 59-87.

Summons R E, Bird L R, Gillispie A L, Pruss S B, Robets M and Sessions A L 2013 Lipid biomarkers in ooids from different locations and ages: Evidence for a common bacterial flora; Geobiology 11(5) 420-436.

Trichet J and Desfarge C 1975 Non-biologically supported organomineralization; Bull. Inst. Ocean de Monaco 14 203-236.

Valdiya K S 1972 Origin of phosphorite of the Late Precambrian Gangolihat dolomite of Pithoragarh, Kumaun Himalaya; Sedimentology 19 115-128.

Van Tuyl F M 1916 The present status of dolomite problem; Science 44 688-690.

Vasconcelos C and McKenzie J A 1997 Microbial mediation of modern dolomite precipitation and diagenesis under anoxic conditions (Lagoa Vermelha, Rio de Janeiro, Brazil); J. Sedim. Res. 67 378-390.

Vasconcelos C, McKenzie J A, Bernasconi S, Grujic D and Tien A J 1995 Microbial mediation as a possible mechanism for dolomite formation; Nature 377 220-222. 
Von der Borch C C and Lock D 1979 Geological significance of Coorong dolomites; Sedimentology 26813 824.

Von Stackelberg U 1972 Faziesverteilung in sedimentendes Indich- Pakistanischen Kontinental-Randes (Arabisches Meer) Meteor Forschungsgebn; Reiche C9 1-73.

Vora K H and Almeida F 1990 Submerged reef systems on the central western continental shelf of India; Mar. Geol. $91255-262$.

Warthmannn R, Lith Y V, Vasconcelos C, McKenzie J A and Karpoff A M 2000 Bacterially induced dolomite precipitation in anoxic culture experiments; Geology 12 1091-1094.

Wells A J and Illing L V 1964 Present day precipitation of calcium carbonate in the Persian Gulf; Dev. Sedimentol. 1 429-435.

Wiedicke M, Kudras H R and Hubscher C 1999 Oolitic beach barriers of the last glacial sea-level low stand at the outer Bengal shelf; Mar. Geol. 157 7-18.

Corresponding editor: N V CHALAPATHI RAO
Wilson J L 1975 Carbonate facies in geological history; Springer-Verlag, New York, 471p.

Wright D T 1997 An organogenic origin of widespread dolomite in the Cambria Eilean Dubh Formation, northwestern Scotland; J. Sedim. Petrol. 67 54-64.

Wright D T 2000 Benthic microbial communities and dolomite formation in marine and lacustrine environments- a new dolomite model; In: Marine authigenesis from global to microbial (eds) Glenn C R, Lucas J and Prevot L, SEPM Spec. Publ. 66 7-20.

Xu H, Zhao X, Eberli G P, Liu X, Zhu Y, Cai Y, Luo W, Yan B G, Zhang B, Wei K and Shi J 2015 Biogenic carbonate formation and sedimentation in the Xisha Islands: evidences from living Halimeda; Acta Oceanol. Sin. 34 $62-73$.

Yates K K and Robbins L A 1999 Radioisotope tracer studies of inorganic carbon and $\mathrm{Ca}$ in microbially derived $\mathrm{CaCO}_{3}$; Geochim. Cosmochim. Acta 63 129-136. 